\title{
Multidrug resistance mediated by the breast cancer resistance protein BCRP (ABCG2)
}

\author{
L Austin Doyle ${ }^{*, 1,2,3}$ and Douglas D Ross ${ }^{1,2,3,4}$ \\ ${ }^{1}$ The University of Maryland Greenebaum Cancer Center, MD, USA; ${ }^{2}$ Department of Medicine, University of Maryland School of \\ Medicine, MD, USA; ${ }^{3}$ Department of Pathology, University of Maryland School of Medicine, MD, USA; ${ }^{4}$ Baltimore VA Medical \\ Center, Baltimore, MD 21201, USA
}

Observations of functional adenosine triphosphate (ATP)dependent drug efflux in certain multidrug-resistant cancer cell lines without overexpression of P-glycoprotein or multidrug resistance protein (MRP) family members suggested the existence of another ATP-binding cassette (ABC) transporter capable of causing cancer drug resistance. In one such cell line (MCF-7/AdrVp), the overexpression of a novel member of the $G$ subfamily of ABC transporters was found. The new transporter was termed the breast cancer resistance protein (BCRP), because of its identification in MCF-7 human breast carcinoma cells. BCRP is a 655 amino-acid polypeptide, formally designated as ABCG2. Like all members of the ABC G (white) subfamily, BCRP is a half transporter. Transfection and enforced overexpression of BCRP in drug-sensitive MCF-7 or MDA-MB-231 cells recapitulates the drug-resistance phenotype of MCF-7/AdrVp cells, consistent with current evidence suggesting that functional BCRP is a homodimer. BCRP maps to chromosome 4q22, downstream from a TATA-less promoter. The spectrum of anticancer drugs effluxed by BCRP includes mitoxantrone, camptothecin-derived and indolocarbazole topoisomerase I inhibitors, methotrexate, flavopiridol, and quinazoline ErbB1 inhibitors. Transport of anthracyclines is variable and appears to depend on the presence of a BCRP mutation at codon 482. Potent and specific inhibitors of BCRP are now being developed, opening the door to clinical applications of BCRP inhibition. Owing to tissue localization in the placenta, bile canaliculi, colon, small bowel, and brain microvessel endothelium, BCRP may play a role in protecting the organism from potentially harmful xenobiotics. BCRP expression has also been demonstrated in pluripotential 'side population' stem cells, responsible for the characteristic ability of these cells to exclude Hoechst 33342 dye, and possibly for the maintenance of the stem cell phenotype. Studies are emerging on the role of BCRP expression in drug resistance in clinical cancers. More prospective studies are needed, preferably combining BCRP protein or mRNA quantification with functional

*Correspondence: LA Doyle and DD Ross, University of Maryland Greenebaum Cancer Center, 22 South Greene Street, Baltimore, MD 21201, USA; E-mail: adoyle@umm.edu,dross@som.umaryland.edu This article is a 'United States Government Work' paper as defined by the US Copyright Act. assays, in order to determine the contribution of BCRP to drug resistance in human cancers.

Oncogene (2003) 22, 7340-7358. doi:10.1038/sj.onc.1206938

Keywords: cancer; drug resistance; $\mathrm{ABC}$ transporter; BCRP; ABCG2

Multidrug resistance (MDR) in cancer cells is the simultaneous development of resistance to a variety of anticancer drugs that appear to be structurally and mechanistically unrelated. One type of MDR is characterized by the decreased accumulation of hydrophobic natural product drugs. In some multidrug-resistant cells, drug efflux is mediated by an adenosine triphosphate (ATP)-dependent membrane transporter termed P-glycoprotein (Pgp), the product of the MDR1 gene (Juliano and Ling, 1976). Pgp functions as an active outward transport mechanism for a variety of molecules, including certain chemotherapeutic drugs. As data accumulated regarding the role of Pgp in drug resistance, it became clear that other transporters could confer resistance to cytotoxic agents. The MDR protein 1 (MRP1) gene was cloned from a multidrug-resistant lung cancer cell line and, like Pgp, was found to be a member of the ATP-binding cassette (ABC) superfamily of transporter genes (Cole et al., 1992). Transfection studies indicated that, similar to MDR1, MRP1 overexpression is sufficient to confer resistance to a broad profile of lipophilic, natural product antineoplastics. MRP1 was the first identified member of a family of genes encoding multispecific organic anion transporter (MOAT) proteins (Borst et al., 1999). Two other homologues of MRP1, the cMOAT/MRP2 and MRP3 genes encode proteins that mediate MDR when transfected into drug-sensitive cell (Borst et al., 1999). All of these membrane-embedded proteins act as drug efflux pumps, preventing cytotoxic agents from reaching lethal levels within cells.

A number of cell lines selected for resistance to the anthracenedione mitoxantrone were discovered to have a transporter activity without overexpression of MDR1 or MRP1 (Dietel et al., 1990; Taylor et al., 1991; Nakagawa et al., 1992; Futscher et al., 1994; Hazlehurst et al., 1999). These cell lines were highly resistant 
to mitoxantrone, with cross resistance to doxorubicin and daunorubicin, but were not resistant to vinblastine. The mitoxantrone-resistant breast cancer cell line MCF-7/MX was demonstrated to have markedly decreased accumulation of radiolabeled mitoxantrone, which was not reversed by verapamil (Nakagawa et al., 1992). The enhanced efflux of mitoxantrone in these cells was blocked by sodium azide or 2,4-dinitrophenol, suggesting an ATP-dependent transporter activity. The MCF-7/MX cell line was also found to be highly resistant to the camptothecin analogs topotecan, 9aminocamptothecin, CPT-11 and SN-38, but was only mildly crossresistant to the parent compound camptothecin (Nakagawa et al., 1992).

A pattern of MDR similar to that found with mitoxantrone selection was found in another breast cancer subline made resistant to doxorubicin in the presence of the Pgp inhibitor verapamil (Chen et al., 1990). The resulting doxorubicin-resistant subline, MCF-7/AdrVp, did not overexpress Pgp or MRP1 and exhibited a cross resistance pattern of high resistance to daunorubicin, mitoxantrone, rubidazone, VM-26, and melphalan, but only minimal resistance to vinca alkaloids, actinomycin D, cisplatinum, or paclitaxel. The relative resistance of the $\mathrm{MCF}-7 / \mathrm{AdrVp}$ subline to mitoxantrone was strikingly higher than the resistance to the selecting agent doxorubicin (Lee et al., 1997). The MCF-7/AdrVp subline did not display the altered subcellular distribution of drug seen in many cell lines that express MRP1 (Lee et al., 1997). Decreased accumulation of daunorubicin and the fluorescent dye rhodamine 123 throughout the cytoplasm was seen in MCF-7/AdrVp cells (Doyle et al., 1995; Lee et al., 1997). Although this decreased accumulation was not reversed by cyclosporin A, depletion of ATP resulted in complete abrogation of the enhanced efflux of both daunorubicin and rhodamine (Lee et al., 1997). These findings led to the hypothesis that an ATP-dependent xenobiotic transporter contributed to the MDR phenotype of MCF-7/AdrVp cells.

\section{Identification of the BCRP gene}

Our laboratory was able to identify a novel ABC transporter in MCF-7/AdrVp cells, and to demonstrate that the enforced expression of the transporter in drugsensitive MCF-7 cells recapitulated the drug-resistant phenotype of the MCF-7/AdrVp cells (Doyle et al., 1998). We named the new transporter breast cancer resistance protein (BCRP), because it was derived from a resistant breast cancer cell line. To isolate BCRP, we examined RNA transcripts overexpressed in the MCF7/AdrVp subline relative to parental MCF-7 cells by RNA fingerprinting, a variation of differential display (Doyle et al., 1998). Gel bands that represented differentially expressed cDNAs were isolated, amplified by PCR, ligated into a TA cloning vector and transfected into Escherichia coli cells. One differentially expressed PCR product insert identified a $2.4 \mathrm{~kb}$ mRNA species that was confirmed by Northern analysis to be markedly overexpressed in MCF-7/AdrVp cells, compared with MCF-7 (Doyle et al., 1998). Protein database searches of the deduced amino-acid sequence revealed a high degree of homology to members of the $\mathrm{G}$ or white subfamily of ATP-binding cassette (ABC) transport proteins. The PCR product was radiolabeled and used as a probe to isolate a full-length cDNA from a lambda phage library derived from MCF-7/AdrVp. The fulllength cDNA coded for a novel 655 amino-acid protein with properties of a half-transporter, which is characteristic for members of the ABCG subfamily. A BLAST-N search of the nonredundant database of GenBank human expressed sequence tag (EST) entries for homology to the BCRP cDNA sequences revealed that a portion of the $3^{\prime}$ end of BCRP CDNA had near identity to clone EST157481, one of 21 new genes predicted by Allikmets et al. (1996) to be in the human ABC transporter family on the basis of EST database analysis.

To determine whether BCRP was the putative mitoxantrone transporter described in many atypical multidrug-resistant cell lines, we examined a number of these cancer cell lines selected for BCRP expression (Ross et al., 1999). A variety of mitoxantrone-resistant cell lines were found to overexpress BCRP mRNA markedly, including sublines of human breast carcinoma (MCF-7), colon carcinoma (S1 and HT29), gastric carcinoma (EPG85-257), fibrosarcoma (EPF86-079), and myeloma (8226). These results suggested that BCRP overexpression was likely to be a major cellular defense mechanism elicited in response to exposure to mitoxantrone.

Subsequent to our initial report of BCRP, a cDNA essentially identical to BCRP was cloned by Allikmets et al. (1998) by extending EST 157481, and given the name ABCP, relating to its expression in the placenta. A cDNA essentially the same as BCRP was also cloned from the mitoxantrone-resistant colon cancer cell line S1-M1-80 by Miyake et al. (1999), and given the name MXR, relating to the mitoxantrone resistance phenotype conferred by the expression of the gene. The Human Gene Nomenclature Committee formally designated BCRP as $\mathrm{ABCG}$, or the second member of the $\mathrm{G}$ (white) subfamily of ABC transporters. The gene nomenclature can be found on the $\mathrm{ABC}$ transporter web page (URL: http://www.med.rug.nl/mdl/humanabc.htm). Since most papers in the literature use the original name BCRP, we will employ it for this review.

ABC genes comprise a large superfamily of transporters characterized by extensive conservation of the ATP-binding domains throughout evolution (Higgins, 1995). ABC family members function as ATP-dependent active membrane transporters, translocating molecules across a cell membrane against a concentration gradient. Most functional ABC transporters consist of two ATPbinding domains and two sets of transmembrane domains. In eucaryotes, most ABC genes have all four domains in a single open reading frame. A smaller group of ABC transporters, termed half-transporters, have single transmembrane and ATP-binding domains. Half 
transporters typically form heterodimers to produce a functional protein, such as the TAP1/TAP2 heterodimers involved in peptide transport into the endoplasmic reticulum (Abele and Tampe, 1999). The first genetic marker described in Drosophila, the white protein, is an ABC half-transporter closely related to BCRP. The Drosophila white protein forms complexes with two other white-related half transporters: brown to transport guanine or scarlet to transport tryptophan, the precursors to eye pigments (Ewart and Howells, 1998). White/white homodimers are not functional for transport of either tryptophan or guanine (Higgins, 1995).

Analysis of the phylogenetic relationship of BCRP to other members of the ABC transporter superfamily (Figure 1) reveals that BCRP is only distantly related to

\section{ATP Binding Cassette Transporter Superfamily}

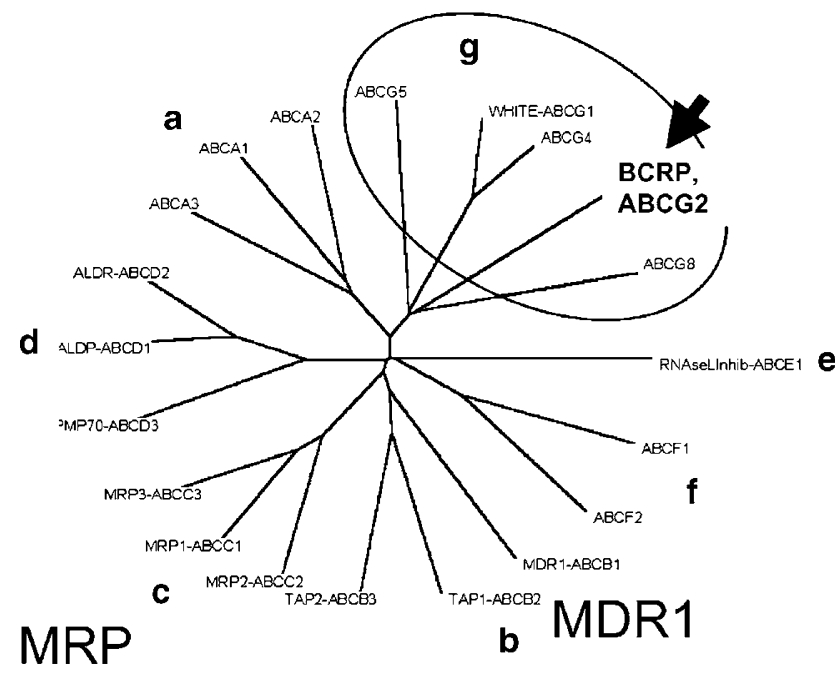

0.1

Figure 1 Relationship of BCRP (ABCG2) amongst ABC transporters. This dendrogram was produced using multiple sequence alignments with Clustal_X 1.8 (Thompson et al., 1997), with graphical representation in a tree diagram using TreeView 1.6 .6
Pgp or MRP1, but is closely related to ABCG1 (Doyle et al., 1998), the human homologue of the Drosophila white (w) gene (Chen et al., 1996; Croop et al., 1997). ABCG1 has 638 amino acids, which are $29.3 \%$ identical to BCRP. In humans, ABCG1 has been recently found to be a regulator of macrophage cholesterol and phospholipid transport (Klucken et al., 2000). Members of the human ABCG subfamily are summarized in Table 1 .

Analysis of the BCRP peptide sequence (Figure 2) reveals a single $\mathrm{ATP} / \mathrm{GTP}$-binding region and $\mathrm{ABC}$ signature motif within a relatively hydrophilic aminoterminal domain (amino acids 1-400), and a relatively hydrophobic carboxyl-terminal domain (amino acids 401-663) containing six putative transmembrane domains and four potential N-glycosylation sites (Doyle et al., 1998). The BCRP or white sequences are similar to one-half of the duplicated Pgp or MRP1 molecule, except that Pgp or MRP1 have the configuration $\mathrm{NH}_{2}-$ (transmembrane domains)-(ATP binding 1)-(transmembrane domains)-(ATP binding 2)- $\mathrm{COOH}$, whereas BCRP or white have $\mathrm{NH}_{2}-$ (ATP binding)-(transmembrane domains)-COOH. Members of the ABCG subfamily are the only known human $\mathrm{ABC}$ transporters with a domain arrangement in which the $\mathrm{ABC}$ fold precedes the transmembrane region.

\section{Comparison of ABC Transporter Families}
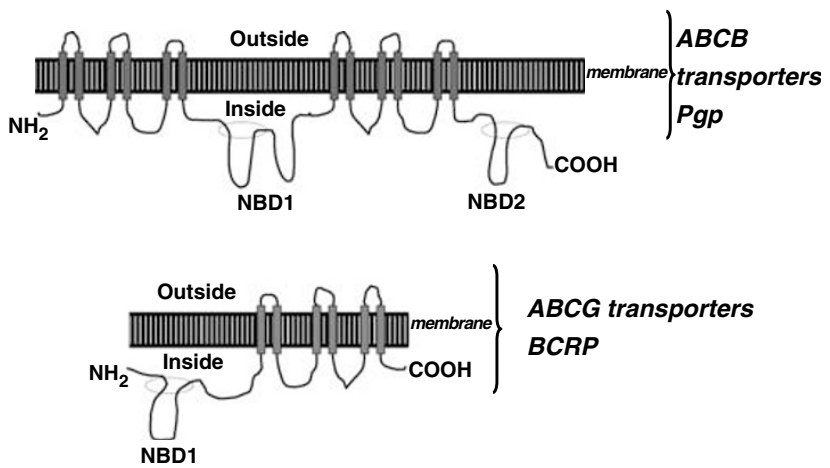

ABCG transporters $B C R P$

Figure 2 Physical structure of BCRP (ABCG2) compared to $\mathrm{ABCB}$ and $\mathrm{ABCC}$ family members (used with permission from Macmillan)

Table 1 Members of the human ABC transporter subfamily G (white) ${ }^{\mathrm{a}}$

\begin{tabular}{|c|c|c|c|c|}
\hline$N_{a m e}{ }^{\mathrm{b}}$ & Chromosome & Amino acids & Tissue & Substrates \\
\hline ABCG1 (white) & $21 \mathrm{q} 22.3$ & 638 & Brain, spleen, lung & Sterols, lipids \\
\hline $\begin{array}{l}\text { ABCG2 (BCRP, } \\
\text { MXR, ABCP) }\end{array}$ & $4 q 22$ & 655 & $\begin{array}{l}\text { Placenta, liver, colon, small bowel, } \\
\text { venules - see Table } 3\end{array}$ & See Table 2 \\
\hline $\mathrm{ABCG} 3$ & $8 \mathrm{p} 12$ & $\begin{array}{l}\text { ? Has unusual ATP-binding } \\
\text { domain - may not be tran- } \\
\text { scribed }\end{array}$ & 一 & - \\
\hline ABCG4 (white 2) & $11 \mathrm{q} 23$ & 646 & - & - \\
\hline ABCG5 (white 3) & $2 \mathrm{p} 21$ & 651 & Liver, small bowel & Sterols? \\
\hline ABCG8 (white 4) & $2 \mathrm{p} 21$ & 673 & Liver, small bowel & Sterols \\
\hline
\end{tabular}

adapted from Muller, M: http://humanabc.4t.com/humanabc.htm.

${ }^{b}$ Human Gene Nomenclature Committee designation (common name) 


\section{Functional configuration of BCRP}

Recent evidence suggests that BCRP functions as a homodimer bridged by disulfide bonds. The initial demonstration that BCRP transfection directly confers MDR supports evidence that BCRP might be able to function by homodimerization (Doyle et al., 1998). Kage et al. (2002) established BCRP transfectants with either Myc- or HA-tagged BCRP. The exogenous BCRP proteins migrated as $70 \mathrm{kDa}$ bands in SDS-PAGE under reducing conditions, but as a $140 \mathrm{kDa}$ complex in the absence of reducing agents. The $140 \mathrm{kDa}$ BCRP complex dissociated into $70 \mathrm{kDa}$ polypeptides with the addition of 2-mercaptoethanol. The $140 \mathrm{kDa}$ BCRP complex was immunoprecipitated with anti-Myc antibody from lysates of cells cotransfected with Myc- and HA-tagged BCRP constructs. The $140 \mathrm{kDa}$ complex reacted with anti-HA and anti-BCRP antibodies. After the addition of reducing agents, a $70 \mathrm{kDa}$ BCRP band was seen, reactive with both anti-HA and anti-Myc antibodies. Furthermore, a dominant-negative mutant of BCRP, with an L554P alteration in the fifth transmembrane domain, was found to inhibit BCRP function partially when cotransfected with BCRP. These results elegantly demonstrate that BCRP forms a homodimer bridged by disulfide bonds. A molecular mass shift from a $72 \mathrm{kDa}$ band under denaturing conditions to a $180 \mathrm{kDa}$ band after treatment with crosslinking agents was also noted in Western blots by Litman et al. (2002), using polyclonal antibodies directed against peptide epitopes of BCRP.

The functional activity of BCRP in transfected insect cells, using a baculovirus-Sf9 cell system, also argues strongly for the activity of the protein as a homodimer (Ozvegy et al., 2001, 2002). In this heterologous system, it is unlikely that any possible heterodimeric partners of BCRP are expressed. These investigators demonstrated that a mutation of BCRP (K86M) in the Walker A nucleotide-binding domain lacked transporter activity, and served as an effective dominant-negative inhibitor of BCRP function when cotransfected with nonmutated BCRP (Ozvegy et al., 2002).

\section{Chromosomal localization studies}

The BCRP gene was mapped using a radiation hybrid panel to human chromosome $4 \mathrm{q} 22$, between the markers D4S2462 and D4S1557 (Knutsen et al., 2000). No other ABC transporter gene had previously been assigned to human chromosome 4. These investigators performed cytogenetic studies on multidrug-resistant MCF7/AdrVp 3000, MCF-7 MX, and S1-M1-80 cells, all of which overexpress BCRP relative to the parental cell lines. The MCF-7/AdrVp 3000 and MCF-7 MX cells demonstrated an amplification peak at 4q21-4q22 by comparative genomic hybridization, while S1-M1-80 cells did not. Fluorescent in situ hybridization (FISH) studies, using chromosome 4 paint markers, demonstrated multiple rearrangements of chromosome 4 in
MCF-7/AdrVp 3000 and MCF-7/MX cells, while S1M1-80 cells had a simple reciprocal translocation between chromosomes 4 and 17. The balanced translocation without amplification of BCRP in S1-M1-80 cells suggests that rearrangement of BCRP in this line results in overexpression through the loss of an inhibitory region or that $\mathrm{BCRP}$ comes under the control of an active promoter in this subline. Spectral karyotyping revealed a balanced translocation, $t(4 ; 17) 9 q 21-q 22: p 13$ in S1-M1-80 and multiple clonal translocations of chromosome 4 in MCF-7/AdrVp3000 and MCF-7/ MX. FISH studies with a bacterial artificial chromosome probe containing BCRP confirmed localization of the gene at $4 q 21-q 22$ in the normal chromosome 4 and showed amplification of BCRP in one translocation juncture in MCF-7/AdrVp 3000 and MCF-7 MX cells. The absence of cytogenetic evidence of coamplification of other regions was interpreted as being consistent with the absence of a half-transporter partner and the sufficiency of BCRP homodimerization to create an active transporter.

\section{Murine and porcine orthologues of BCRP}

The murine orthologue of BCRP was found to be located on chromosome 6 , at a distance of $2829 \mathrm{cM}$ from the centromere (Allen et al., 1999). The BCRP gene demonstrates a new syntenic segment between human chromosome 4 and mouse chromosome 6. Sequencing of mouse cDNA clones revealed two transcripts differing by approximately $200 \mathrm{bp}$ at the $3^{\prime}$ end. Both transcripts contain the same open reading frame of 658 amino acids, corresponding closely in sequence to human BCRP.

Mouse Bcrp1 cDNAs were amplified by high-fidelity PCR with primers based on mouse EST sequences homologous to the $5^{\prime}$ and $3^{\prime}$ ends of human BCRP (Allen et al., 1999). The mouse Bcrpl and human BCRP amino-acid sequences are $81 \%$ identical and $86 \%$ homologous, with very high homology in the ATPbinding region. Hydrophobicity plots of mouse Bcrp1 and human BCRP are almost identical, with six putative transmembrane domains. Four potential sites for Nlinked glycosylation were observed. While the first two are in a likely cytosolic part of the protein, the latter two are closely spaced in the loop between the fifth and sixth transmembrane domains and are likely extracellular. Only one of these latter two glycosylation sites is conserved in the human BCRP sequence.

A 656 amino-acid ABC transporter that is $85 \%$ identical and $90 \%$ homologous to human BCRP was recently isolated from porcine brain capillary endothelial cells (Eisenblatter and Galla, 2002). Termed the brain multidrug resistance protein (BMDP), the protein is expressed in brain tissue in vivo, predominantly within the brain capillary endothelial cells. As a potential xenobiotic transporter, BMDP was postulated to play a role in the blood-brain barrier. In contrast to porcine brain capillary endothelium, low 
expression of BCRP was found in porcine oocytes (Takebayashi et al., 2001).

\section{Organization of the BCRP gene and promoter}

We identified the genomic sequence of BCRP by screening human genomic lambda phage and BAC libraries and by searching the human genome database. The BCRP gene spans over $66 \mathrm{~kb}$ and consists of 16 exons and 15 introns (Bailey-Dell et al., 2001). The exons are small in size, ranging from 60 to $532 \mathrm{bp}$, with the translational start site found in the second exon. The majority of the $5^{\prime}$ untranslated region is in exon 1 . The BCRP promoter is TATA-less, contains a CAAT box, and several putative Sp1 sites downstream from a putative $\mathrm{CpG}$ island. This is similar to the promoters for the MDR1 (ABCB1), MRP1 (ABCC1) and ABCG1 genes, which lack TATA boxes, and have multiple Sp1 sites (Ueda et al., 1987; Zhu and Center, 1994; Langmann et al., 2000). Unlike the ABCG1 (human white homologue) promoter, the BCRP promoter does not contain a sterol response element, strengthening the argument that BCRP is not involved with lipid transport, as is ABCG1 (Klucken et al., 2000; Langmann et al., 2000). We employed a luciferase reporter assay and transient transfection of human breast cancer MCF-7 cells and the human choriocarcinoma cell lines BeWo, JAR, and JEG-3 to investigate promoter activity in deletion constructs made from the BCRP 5' upstream region. These cell lines were used because we found that they have high endogenous expression of BCRP. The reporter analyses indicated that a $312 \mathrm{bp}$ sequence directly upstream from the transcriptional start site conferred basal promoter activity, with positive and negative cis-regulatory elements identified in the region between -1285 and +362 relative to the transcriptional start site (Figure 3) (Bailey-Dell et al., 2001).

Little is known about the regulation of BCRP transcription. Classic enzyme inducers, such as valproic acid, phenytoin, and carbamazepine, induced the tissue expressions of bcrp1 in mouse kidney 1.5-2-fold (Schellens et al., 2002). Phenytoin and carbamazepine also induced Bcrp1 levels significantly in the liver. While dexamethasone was not found to induce Bcrp1, a second study, using a cDNA subtraction technique to compare gene expression in untreated versus hydrocortisonetreated porcine endothelial cells, demonstrated overexpression of porcine BCRP after hydrocortisone (Eisenblatter and Galla, 2002). Elevated basal expression of BCRP, Pgp, and MRP1 were noted in thermoresistant human gastric carcinoma EPG85-257 cells, suggesting the possibility that cellular responses to heat may induce the expression of these transporters (Stein et al., 2002).

\section{Normal allelic variants of $B C R P$}

Partial sequencing of BCRP exons from multiple genomic DNAs demonstrates that the genetic sequence is highly conserved, although single-nucleotide polymorphisms (SNPs) are found. Allelic variation as a result of SNPs results in alterations of the BCRP protein at amino acids 12 (V12M), 141 (Q141K), 206 (I206L), and $590(\mathrm{~N} 590 \mathrm{Y})$, with the most frequent polymorphisms being the exon $2 \mathrm{SNP}$ (G34A) and the exon 5 SNP (C421A), which produce changes in amino acids 12 and 141 (Honjo et al., 2002; Imai et al., 2002a; Zamber et al., 2003). Additionally, a splice variant was found that resulted in deletions of A315 and T316 (Imai et al., 2002a). The effect of these polymorphisms on BCRP function remains to be determined, although one study suggested that the $\mathrm{C} 421 \mathrm{~A} / \mathrm{Q} 141 \mathrm{~K}$ variant may result in

\section{Structure of the Human BCRP (ABCG2) Gene and Promoter}

(Chromosome 4q22)

\section{BCRP 5' Upstream Region (Promoter)}

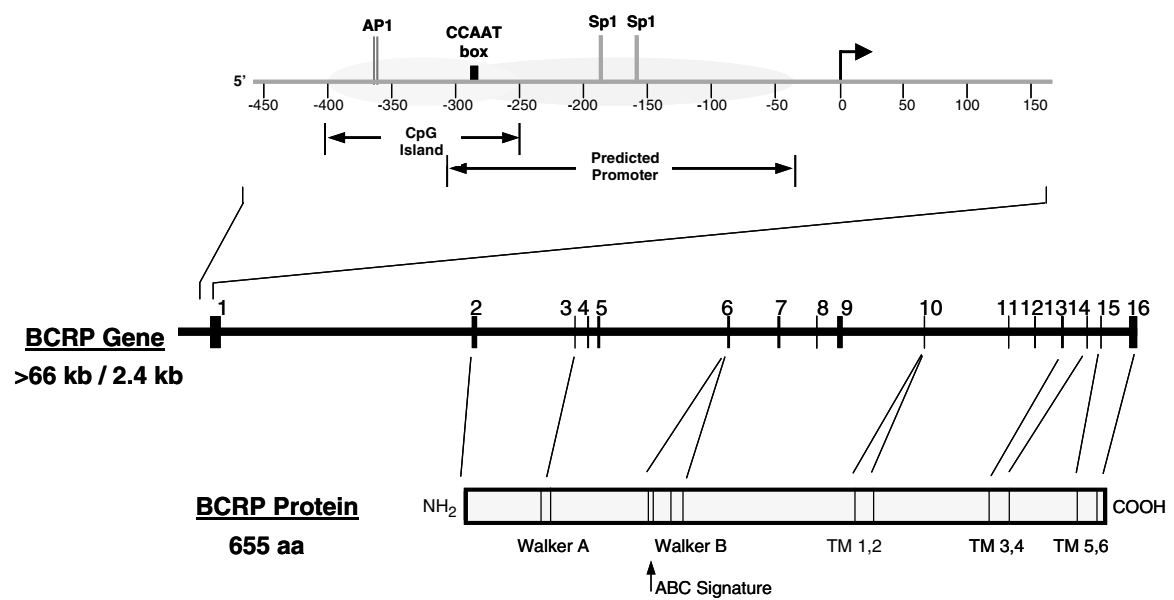

Figure 3 Structure of BCRP gene and promoter. Adapted from (Bailey-Dell et al., 2001), with permission from Elsevier 
very low levels of BCRP protein expression (Imai et al., 2002a). These investigators found that in a normal Japanese population, $39 \%$ were heterozygous and $7 \%$ were homozygous for the variant $\mathrm{C} 412 \mathrm{~A}$ allele.

\section{Resistance phenotype conferred by BCRP expression: substrate specificity}

Our laboratory inserted the full-length cDNA of BCRP into the expression vector pcDNA3, and transfected MCF-7 (Doyle et al., 1998) or MDAMB231 cells with this vector, then isolated clones with high BCRP expression. These clones displayed decreased daunorubicin accumulation and retention by flow cytometry. The BCRP-expressing MCF-7 transfectants were also shown to have decreased accumulation of rhodamine 123 relative to cells transfected with empty vector, and this decreased accumulation was reversed by depletion of ATP (Doyle et al., 1998). The sensitivities of the BCRP-transfected sublines to chemotherapeutic agents were tested by the sulforhodamine-B cytotoxicity assay. To date, the BCRP-overexpressing clones displayed resistance to mitoxantrone, daunorubicin, doxorubicin, and topotecan, but not to cisplatin, paclitaxel, etoposide, or vincristine, compared to control transfectants and parental MCF-7 or MDA MB231 breast cancer cells. The pattern of crossresistance in the transfectants was very similar to that of the original MCF-7/AdrVpresistant cell line, although the degree of resistance to cytotoxic agents in the MCF-7/AdrVp subline was greater than that of transfected cells with comparable levels of BCRP by Northern blotting.

\section{Resistance to mitoxantrone: efflux of fluorescent dyes}

Strong resistance to mitoxantrone characterizes most drug-selected cell lines that overexpress BCRP, even if the selecting agent is not mitoxantrone. For example, MCF-7/AdrVp cells are over 1000-fold resistant to mitoxantrone but only 150 -fold resistant to doxorubicin (Doyle et al., 1998), despite being selected by doxorubicin in the presence of verapamil (Chen et al., 1990). Litman et al. (2000) examined the pharmacodynamics of mitoxantrone and other fluorescent drugs by confocal microscopy in multidrug cell lines overexpressing BCRP. The expression of BCRP correlated with marked decreases in the accumulation of mitoxantrone, daunorubicin, bisantrene, topotecan, prazosin, lysotracker, and rhodamine 123 . The Pgp substrates vinblastine, paclitaxel, and verapamil, and the MRP1 substrate calcein were not extruded from BCRP-overexpressing cells, distinguishing BCRP resistance from that of both Pgp and MRP1. BCRP-expressing cells were also found to be resistant to epirubicin (Brangi et al., 1999). MCF-7 and K562 cells made resistant to doxorubicin encapsulated in polyisohexylcyanoacrylate nanospheres demonstrated BCRP rather than Pgp overexpression (Laurand et al., 2001).

BCRP was found to be an efficient efflux transporter of the fluorescent dye Hoechst 33342 (Scharenberg et al.,
2002). This property is particularly germane to primative stem cells termed 'side population' (SP) stem cells, which strongly efflux Hoechst 33342, and which recently were found to express BCRP (discussed subsequently in this paper).

The aza-anthrapyrazole BBR 3390 (Boeringer Mannheim), which is structurally similar to the anthracenedione structure of mitoxantrone, was demonstrated to have increased efflux in mitoxantrone-resistant 8226 multiple myeloma cells, which overexpress BCRP relative to parental cells (Hazlehurst et al., 1999). The 8226/MR4 subline is 34-fold resistant to BBR 3390. BBR 3390 is a highly fluorescent drug, making it ideal for investigational drug accumulation studies. Decreased accumulation of BBR 3390 in BCRP-transfected cell lines has been demonstrated in our laboratory (Rabindran et al., 2000). BODIPY prazosin, a fluorescent conjugate of the quinazoline alpha blocker prazosin, can also be used to monitor BCRP-mediated efflux (Honjo et al., 2001b).

\section{Efflux of anthracyclines, methotrexate, and rhodamine 123: influence of a mutational 'hot-spot' at codon 482}

Anthracycline resistance and rhodamine efflux were noted in the BCRP-overexpressing MCF-7/AdrVp and S1-M1-80 cell lines but not in 10 other sublines that overexpress BCRP (Honjo et al., 2001a). Sequencing of BCRP in these 12 lines demonstrated that MCF-7/ AdrVp and S1-M1-80 contain a threonine and glycine, respectively, at codon 482, while their parental cell lines, as well as the other 10 resistant cell lines, have an arginine residue at that position. Sequencing of BCRP derived from normal tissues such as placenta reveal arginine at amino acid position 482, indicating that R482 is the 'wild-type' configuration, and that the threonine or glycine substitutions are mutations (R482T or $\mathrm{R} 482 \mathrm{G})$. These results suggest that a mutation at position 482 of BCRP, in the third transmembrane domain, may alter substrate specificity of the transporter to include rhodamine efflux. Transfection studies with a vaccinia virus expression system confirm that rhodamine efflux is observed when BCRP has a glycine or threonine at 482, but does not occur with arginine at 482 (Honjo et al., 2001a). Three mouse cell lines independently selected for doxorubicin resistance were found to acquire mutations of murine Bcrpl at arginine 482, leading to greater resistance to anthracyclines and bisantrene and to increased efflux of rhodamine 123 (Allen et al., 2002a). The Bcrp1 mutations occurred after previous amplification and overexpression of the wildtype gene under doxorubicin selection. The findings demonstrate the crucial role of arginine 482 for BCRP substrate specificity, while suggesting that even unmutated BCRP has a role in anthracycline resistance. A Japanese study also suggested that crossresistance to mitoxantrone was relatively high in cell lines transfected with BCRP R482T as compared with those transfected with BCRP R482 (Komatani et al., 2001). This conclusion was refuted by another study demonstrating high levels of mitoxantrone resistance in cell lines 
expressing wild-type R482 as well as mutated R482G and R482T (Volk et al., 2002a).

As with other anthracyclines, wild-type BCRP does not confer resistance to idarubicin (Abbott et al., 2002). However, MCF-7/AdrVp cells, which overexpress the R482T mutation of BCRP and display considerable resistance to daunorubicin (25-40-fold) (Ross et al., 1995; Doyle et al., 1998), accumulate and retain idarubicin well, and are only minimally resistant to idarubicin (1.8-fold) (Ross et al., 1995).

A high level of ATP-dependent cross resistance to methotrexate was noted in mitoxantrone-selected MCF-7/MX cells, which display considerable overexpression of BCRP (Volk et al., 2000). Furthermore, this methotrexate resistance was reversible with the BCRP inhibitor GF120918. However, in this same work, investigations of the BCRP-transfected MCF-7 or MDAMB-231 cells developed in our laboratory did not find resistance or low accumulation of methotrexate in the transfected cells. Since these MCF-7 or MDAMB231 cells were transfected with BCRP cDNA derived from MCF-7/AdrVp cells, the transfected cells consequently overexpressed the R482T mutation of BCRP. This realization led to further studies of methotrexate transport, which revealed that methotrexate resistance, reversible with GF120918, correlated with BCRP expression in cell lines that overexpressed wild-type BCRP, but not the mutant forms (R482T or R482G) (Volk et al., 2002b).

Mutations of BCRP at position 482 have been investigated using the Baculovirus-Sf9 insect system (Ozvegy et al., 2001, 2002). BCRP transporters having different amino acids (Arg, Gly or Thr) at position 482 were expressed in Sf9 cells and membranes from these cells were studied for ATPase and transport characteristics. All three BCRP proteins had high basal, vanadate-sensitive ATPase activity. However, only the mutant $482 \mathrm{G}$ and $482 \mathrm{~T}$ transporters showed any drugstimulated ATPase activity, when measured in the presence of known BCRP substrates. Fumitremorgin C (FTC), a specific inhibitor of BCRP (described subsequently), decreased the ATPase activity for both wild-type and 482 mutant variants of BCRP.

\section{Resistance to topoisomerase I inhibitors}

Mitoxantrone-resistant cell lines had frequently been demonstrated to have crossresistance to camptothecinderived topoisomerase I poisons (Nakagawa et al., 1992). Experiments with BCRP-transfected cells also demonstrated low-level resistance to the planar aromatic topoisomerase I inhibitors topotecan (Rabindran et al., 2000) and irinotecan, as well as to SN-38, the active metabolite of irinotecan, reversible with FTC, a specific inhibitor of BCRP. This information was used as the basis for investigating the role of BCRP in cancer cells made resistant to topoisomerase I inhibitors in vitro (Maliepaard et al., 1999). Resistant ovarian cell lines T8 and MX3 were developed by exposure of IGROV-1 tumor cells to topotecan or mitoxantrone, respectively. Both lines are resistant to topotecan, SN-38, 9-amino- camptothecin, and mitoxantrone, but are not resistant to camptothecin, doxorubicin, paclitaxel, 5-FU, or cisplatin. Topotecan and mitoxantrone levels are markedly decreased in the resistant cell lines by a rapid, energy-dependent efflux mechanism, in the absence of overexpression of MRP1 or Pgp. Northern blotting revealed that BCRP mRNA was undetectable in the IGROV1 cells, while abundant expression was observed in the T8 and MX3 cells. The expression levels of BCRP in various revertant $\mathrm{T} 8$ sublines were qualitatively correlated to the level of resistance. Another topotecan-resistant breast cancer cell line, MCF-7/TPT300, with increased topotecan efflux, was also derived from MCF-7 parent cells (Yang et al., 2000). MCF-7/TPT300 cells did not overexpress Pgp or MRP1, but had overexpression of BCRP, demonstrated by Northern and Western blotting. There was a lack of resistance to doxorubicin in topotecan-selected resistant cancer cells expressing BCRP, in contrast to the doxorubicin resistance demonstrated in mitoxantrone-resistant or BCRP-transfected cells.

Irinotecan is transformed to $\mathrm{SN}-38$, an active metabolite that is further glucuronidated by uridine diphosphate glucuronosyltransferases (UGTs) in cells. An SN-38-resistant PC-6/SN2-5 small-cell lung cancer cell line was derived from parental PC-6 cells (Kawabata et al., 2001b). A more highly resistant PC-6/SN2-5H cell line was also derived. These cell lines are 20- and 50-fold resistant to $\mathrm{SN}-38$, respectively, and have reduced intracellular accumulation of the drug with crossresistance to mitoxantrone and to other topoisomerase I inhibitors (Kawabata et al., 2001b). No alterations in topoisomerase I gene sequence or activity, and no differences in UGT1A1 enzyme content or total UGT enzyme activity were seen in the resistant cells. The level of BCRP expression in these sublines correlated with resistance to $\mathrm{SN}-38$. BCRP-antisense oligonucleotides significantly enhanced the SN-38 sensitivity of the resistant cells with reduction of BCRP mRNA levels and increased intracellular accumulation of $\mathrm{SN}-38$ (Kawabata et al., 2001b).

Resistance to two potent indolocarbazole topoisomerase I inhibitors, NB-506 and J-107088, was found to be mediated by BCRP (Komatani et al., 2001). An NB-506resistant mouse fibroblast cell line and its parental cell line were analysed for gene expression by oligonucleotide microarray. Of 34,020 gene sequences analysed, the BCRP gene showed the highest relative increase in expression (31-fold).

Differences in structure of the topoisomerase I inhibitors appear to determine the specificity of the drugs as BCRP substrates. Cancer cells that express BCRP are not resistant to camptothecin itself, or to the camptothecin analogs BNP1350, DX8951f, or NX211 (Ishii et al., 2000; Maliepaard et al., 2001b; Van Hattum et al., 2001; Van Hattum et al., 2002). Studies of SN-38and irinotecan-resistant PC-6 sublines, which overexpress BCRP, also demonstrated that these cells were not resistant to the clinically promising water-soluble camptothecin analog DX-8951f (Ishii et al., 2000). However, ovarian cancer cells made resistant to 
DX-8951f itself overexpressed BCRP but not Pgp, MRP1, or LRP (Van Hattum et al., 2001). The DX8951f-resistant ovarian cancer cell line was much more resistant to topotecan, $\mathrm{SN}-38$, and mitoxantrone than it was to the selecting agent. Experimental data suggest that the accumulation of camptothecin analogs in BCRP-expressing cells is related to the polarity of the molecule (Yoshikawa et al., 2002). Nucleophilic groups at the ninth or tenth position of the camptothecin A ring facilitate interaction with BCRP. For example, BCRP expression confers resistance to 9-aminocamptothecin but not 9-nitrocamptothecin, associated with decreased intracellular concentrations of the former but not the latter (Rajendra et al., 2002). ST1481, a lipophilic 7-modified camptothecin analog with good oral bioavailability, was reported to be a poor substrate for BCRP (Perego et al., 2001).

\section{Flavopiridol resistance}

Flavopiridol is an $N$-methylpiperidinyl chlorophenyl flavone, which was the first cyclin-dependent kinase inhibitor used in human clinical trials (Senderowicz, 1999). Flavopiridol arrests cell growth at both G1 and G2 junctures and induces apoptosis as demonstrated by Annexin-V labeling and cytologic studies. Previously reported mechanisms of resistance to flavopiridol involve alterations in apoptosis due to overexpression of bcl-2, cyclin-D1, and p53 inactivation. Resistance to flavopiridol has not been seen in MDR cells overexpressing Pgp, MRP1, or MRP2, but was observed in the mitoxantrone-resistant cell lines 8226/MR20 and MCF-7/MR, which overexpress BCRP (Schlegel et al., 1999). The myeloma cell line 8226/MR20 and the breast cancer subline MCF-7/MR have 4.8- and 3.2-fold resistance to flavopiridol, respectively. MCF-7 cells made 30-fold resistant to flavopiridol are also highly crossresistant to mitoxantrone, topotecan, and SN-38, but not to 5-FU or paclitaxel (Robey et al., 2001b). Northern analysis of this MCF-7/FLV1000 subline revealed overexpression of the BCRP gene. Furthermore, flavopiridol, at a concentration of $100 \mu \mathrm{M}$, was able to antagonize mitoxantrone transport from both mitoxantrone-resistant S1-M1-80 cells and the flavopiridol-resistant MCF-7/FLV1000 subline. In BCRP-transfected MCF-7 cells, flavopiridol was also effective in blocking mitoxantrone efflux (Robey et al., 2001b).

\section{BCRP transport of drug conjugates}

Preliminary investigations have examined whether BCRP may transport drug conjugates analogous to the glutathione conjugates transported by MRP1. Many of the cytotoxic drugs extruded by BCRP, such as irinotecan, SN-38, and epirubicin, are detoxified by glucuronidation with UDP-glucuronyltransferases. Brangi et al. (1999) compared glucuronidation of 4methylumbelliferone (4-MU), SN-38, mitoxantrone, and epirubicin in the mitoxantrone-resistant colon cell line S1-M1-80 and the doxorubicin-resistant MCF-7/AdrVp
3000 breast cancer cell lines to that of the parental cell lines. The MCF-7/AdrVp 3000 cells demonstrated increased glucuronide formation for 4-MU and epirubicin relative to the parental cells. The extent of glucuronidation with each compound was similar between the sensitive and resistant colon cancer cell lines, which have increased UDP-glucuronosyltransferase activity relative to the breast cancer sublines, suggesting that glucuronidation is not rate limiting for the resistance mechanism in the S1-M1-80 cells.

To determine whether BCRP transports SN-38 and/ or SN-38 glucuronide, Nakatomi et al. (2001) isolated membrane vesicles from SN-38-resistant PC-6/SN2-5H cells, which overexpress BCRP, and from the parental PC-6 small-cell lung cancer line (Kawabata et al., $2001 \mathrm{~b})$. The concentrations of free SN-38 and SN-38glucuronide within the membrane vesicles were measured by HPLC. Both SN-38 and SN-38 glucuronide were transported into the vesicles of PC-6/SN2-5 cells, in an ATP-dependent fashion, but not into the vesicles of PC-6 cells. These findings suggest that BCRP transports SN-38 glucuronide and confers resistance to SN-38. However, the $V_{\max } / K_{\mathrm{m}}$ ratio for SN-38 in PC-6/SN2-5H membrane proteins was substantially higher than the ratio of those kinetic parameters for $\mathrm{SN}$-38-glucuronide, suggesting that BCRP interacts directly with SN-38 and preferentially transports $\mathrm{SN}-38$ rather than $\mathrm{SN}-38$ glucuronide (Nakatomi et al., 2001).

\section{Modulation of BCRP transport}

\section{Fumitremorgin $C$}

Most inhibitors of Pgp, such as verapamil, cyclosporin A, PSC-833, and the new Pgp antagonists XR9576 and LY335979, do not increase drug accumulation or cytotoxicity in cells expressing BCRP (Litman et al., 2000). However, a number of potent inhibitors of BCRP transport have been described. Even before the discovery of the BCRP transporter, the drug FTC had been described as reversing mitoxantrone resistance and transport (Rabindran et al., 1998). Rabindran and Greenberger used the mitoxantrone-resistant colon cancer cell line S1-M1-3.2 in a cell-based screen with a library of extracts derived from a variety of microorganisms. Extracts that had little or no toxicity by themselves but that, when combined with mitoxantrone, showed substantially increased cell death were analysed further. One extract from a solid medium fermentation broth of Aspergillus fumigatus was found to be highly active. The pharmacologically active ingredient in this broth was purified by chromatographic methods. The active ingredient was shown to be FTC, belonging to a class of diketopiperazines that are potent mycotoxins. FTC caused tremors in cockerels at $25 \mathrm{mg} / \mathrm{kg}$ orally (Cole and Cox, 1981). FTC, at a $5 \mu \mathrm{M}$ concentration, significantly increased the toxicity of mitoxantrone (93-fold), doxorubicin (26-fold), topotecan (24-fold), and bisantrene (25-fold). At $1 \mu \mathrm{M}$, FTC was also 
demonstrated to increase the amounts of mitoxantrone and doxorubicin retained by S1-M1-3.2 cells.

FTC does not reverse resistance to cells that overexpress Pgp (S1-B1-20, 8226/DOX6) or MRP1 (HL60/AR) (Rabindran et al., 1998). FTC was found, however, to reverse resistance to mitoxantrone and doxorubicin in a breast cancer cell line (MCF-7/mtxR) selected in mitoxantrone and expressing BCRP, as well as with the MCF-7/AdrVp cell line. We evaluated the activity of FTC in cells transfected with BCRP to confirm that FTC could reverse resistance mediated by this transporter (Rabindran et al., 2000). Cells transfected with the pcDNA3 vector (MCF-7/pcDNA3) or the BCRP expression construct (MCF-7/BCRP) were exposed to cytotoxic drugs in sulforhodamine blue cytotoxicity assays, with or without the addition of FTC. FTC, at $5 \mu \mathrm{M}$, almost completely reversed resistance mediated by $\mathrm{BCRP}$ in vitro to mitoxantrone, doxorubicin, and topotecan. FTC also enhanced the toxicity of topotecan but not mitoxantrone in vectortransfected MCF-7 cells. The enhanced cytotoxicity of topotecan by FTC may be related to the known lowlevel expression of BCRP in parental MCF-7 cells, but a second, FTC-sensitive, mechanism of drug resistance cannot be completely discounted (Rabindran et al., 2000). Flow cytometric measurement of the inhibition of mitoxantrone or prazosin efflux by FTC correlates with levels of BCRP mRNA by Northern analysis, and as such, constitutes a sensitive and specific functional assay for BCRP (de Bruin et al., 1999; Robey et al., 2001a).

Resistance to flavopiridol is reversible by FTC, and FTC is also able to enhance the accumulation and inhibit the efflux of the fluorescent aza-anthrapyrazole drug BBR 3390 (Rabindran et al., 2000; Robey et al., 2001b). Sensitivity to flavopiridol has also been restored by concurrent exposure to BIB-E, a dipyridamole analog that inhibits BCRP-mediated drug export (Schlegel et al., 1999).

BCRP-mediated drug efflux can also be inhibited by other fumitremorgin-type indolyl diketopiperazines (van Loevezijn et al., 2001). A library of diastereoisomeric mixtures of these compounds, synthesized by solid phase techniques, were screened for BCRP inhibitory properties in both the Igrov1/T8 human ovarian carcinoma cell line and the mouse T6400 cell line. The T6400 cell line is a topotecan-selected subline of the embryo fibroblast line MEF3.8, lacking functional genes encoding mouse Pgp and Mrp1. This subline is highly resistant to topotecan and mitoxantrone and expresses the murine homologue Bcrp1 (Allen et al., 1999). Structure-activity relationship studies of the fumitremorgin-related compounds demonstrated that several analogs had potent effects on mitoxantrone accumulation and MDR in both cell systems. The tetracyclic FTC analog Ko143 was found to be a highly potent and specific inhibitor of BCRP, without the neurotoxicity that is associated with FTC, as assessed in murine systems (Allen et al., 2002b). Ko143, at $100 \mathrm{~nm}$ concentration, modulated BCRPmediated transport of mitoxantrone, but did not modulate P-gp or MRP1-mediated efflux (Minderman et al., 2002a).

\section{Novobiocin}

We have demonstrated that partial reversal of BCRPmediated drug resistance and transport can be achieved by coincubation of resistant cells with novobiocin, a coumermycin antibiotic (Doyle et al., 1996). Modulation of BCRP-mediated resistance by novobiocin and FTC was studied using a novel coculture comparative growth assay (Hausner et al., 1999). MCF-7 cells, stably transfected with pcDNA-3 BCRP, were compared with MCF-7 cells transfected with a control plasmid. One cell line of each coculture was permanently labeled by stably expressing the yellow fluorescent protein. The coculture was exposed to vincristine, mitoxantrone, topotecan, daunorubicin, and SN-38, with or without the addition of putative inhibitors FTC or novobiocin. The coculture was exposed to drugs for 4 days, evaluated by flow cytometry and the average daily selection rate was calculated from the ratio of fluorescent and nonfluorescent cells in exposed cocultures compared to baseline cocultures. BCRP-overexpressing MCF-7 cells were selected by mitoxantrone, topotecan, SN-38, and daunorubicin. Novobiocin decreased the selection rate of daunorubicin and FTC completely reverted the selective advantage of BCRP-expressing cells exposed to topotecan or mitoxantrone.

\section{GF120918}

GF120918, an acridone carboxamide, is a secondgeneration Pgp inhibitor developed by GlaxoSmithKline, which increases drug accumulation and cytotoxicity in cells expressing BCRP (de Bruin et al., 1999). Higher concentrations of GF120918 are required to reverse resistance in BCRP-expressing cells than in Pgp-expressing cells. GF120918 does not sensitize MRP1-overexpressing MCF-7/VP-16 cells to etoposide (de Bruin et al., 1999). GF120918 has the advantage over FTC of synthetic production, making large-scale production of this agent more feasible. GF120918 also does not have neurotoxicity, the principal side effect of FTC. The disadvantage of GF120918, as a laboratory or clinical tool, is that it is a less specific inhibitor of BCRP than is FTC.

GF120918 increases the cytotoxicity and accumulation of mitoxantrone and topotecan in BCRP-expressing cells. In the drug-resistant human ovarian cancer lines T8 and MX3, developed by exposure of Igrov1 cells to topotecan and mitoxantrone, respectively, resistance associated with overexpression of BCRP was completely abrogated by GF120918 at a nontoxic dose of $100 \mathrm{~nm}$ (Maliepaard et al., 2000). Reversal of resistance to the promising hydrophilic topoisomerase I inhibitor DX9581f by GF120918, in cells overexpressing BCRP, is variable and may depend on the cell line (Ishii et al., 2000; Van Hattum et al., 2001).

\section{Other BCRP substrate/inhibitors}

The ErbB1 tyrosine kinase inhibitor CI1033 inhibits BCRP-mediated efflux of topotecan and SN-38, leading 
to synergistic cytotoxicity with these agents in glioblastoma and colon cancer cells (Erlichman et al., 2001). CI1033 enhanced the uptake and cytotoxicity of SN-38 and topotecan in cells transfected with BCRP but not empty vector, suggesting that CI1033 is a substrate for this efflux pump. Erlichman et al. (2001) demonstrated protein expression of BCRP in unselected HCT8 colorectal carcinoma cells as well as T98G glioblastoma cells by immunoblotting studies with a monoclonal antibody reactive to $\mathrm{BCRP}$. The expression of $\mathrm{BCRP}$ in these cell lines correlated with the ability of CI1033 to modulate the cytotoxicity of topotecan and SN-38 in the cells. In contrast, BCRP levels were much lower in PC-3 or Ovcar-3, two cell lines in which CI1033 failed to modulate SN-38 cytotoxicity.

The accumulation of CI1033 in MDA-MB-231 cells transfected with empty vector or BCRP was measured by HPLC (Erlichman et al., 2001). This analysis demonstrated that CI1033 accumulation was 4.9-fold lower in cells transfected with BCRP, suggesting that CI1033 is itself a substrate for BCRP, and providing an explanation for the drug's ability to inhibit BCRPmediated efflux of cytotoxic agents.

Another quinazoline ErbB1 inhibitor, Iressa (ZD1839), has also been shown to cause potent BCRP inhibition and to enhance the oral bioavailability of topotecan and irinotecan in mice (Schuetz et al., 2002). In Saos cells transfected with BCRP, Iressa at a concentration less than $1 \mu \mathrm{M}$ reversed topotecan, irinotecan and SN-38 resistance. In mice, oral Iressa (100 mg/ $\mathrm{kg}$ ) markedly increased the oral bioavailability of topotecan and irinotecan. In contrast to structurally related CI1033, Iressa is apparently not a substrate for BCRP transport.

The rauwolfia alkaloid reserpine, a prototypical inhibitor of Pgp, was also found to be an effective inhibitor of BCRP function in stem cell populations (Zhou et al., 2001). The pipecolinate derivatives VX-710 (biricodar, Incel) and VX-853 were found to be effective inhibitors of drug efflux mediated by Pgp, MRP1, and BCRP in acute myeloid leukemia cells (Baer et al., 2002).

Estrogen agonists and antiestrogens were found recently to have potent BCRP antagonistic activity (Sugimoto et al., 2003). Using BCRP-transfected K562 cells, strong BCRP-reversing activity was found for diethylstilbesterol, and estrone. BCRP antagonist activity was also found for the estrogen antagonists tamoxifen and toremifene, and for the tamoxifen derivatives TAG-11 and TAG-139.

Molecular imaging of the functional transport activity of $\mathrm{ABC}$ transporters in vivo with radiopharmaceuticals may allow noninvasive monitoring of chemotherapy and MDR gene therapy agents. Chen et al. (2000) investigated the transport of $99 \mathrm{mTc}$-tetrofosmin, a candidate radiopharmaceutical substrate of ABC transporters in cells overexpressing BCRP. Neither 99mTcSestimibi, a previously validated MDR imaging agent, nor $99 \mathrm{mTc}$-Tetrofosmin was a substrate for BCRP, although both agents were transported by cells overexpressing Pgp.
Table 2 Substrate dyes, drugs, and inhibitors of BCRP

\begin{tabular}{|c|c|c|}
\hline Drugs & $\begin{array}{l}\text { Dyes/natural } \\
\text { substrates }\end{array}$ & Inhibitors \\
\hline Mitoxantrone & Rhodamine $123^{\mathrm{a}}$ & $\begin{array}{l}\text { Fumitremorgin C } \\
\text { (FTC) }\end{array}$ \\
\hline Topotecan & Lysotracker & $\begin{array}{l}\text { FTC analogues } \\
\text { (Kol43) }\end{array}$ \\
\hline Irinotecan, SN-38 & Prazocin-BODIPY & GF120918 \\
\hline $\begin{array}{l}\text { 9-Aminocamptothe- } \\
\text { cin }\end{array}$ & Hoechst 33342 & BIB-E \\
\hline Doxorubicin $^{\mathrm{a}}$ & Pheophorbide a & Flavopiridol \\
\hline Daunorubicin ${ }^{\mathrm{a}}$ & Protoporphyrin IX & CI1033 \\
\hline Epirubicin ${ }^{\mathrm{a}}$ & Hydrocortisone? & Iressa \\
\hline Idarubicinol $^{\mathrm{a}}$ & Estradiol 17- $\beta ?$ & Novobiocin \\
\hline Flavopiridol & Estrone? & Reserpine \\
\hline CI1033 & & VX-710 (biricodar) \\
\hline BBR3390 & & VX-853 \\
\hline Methotrexate $^{\mathrm{a}}$ & & $\begin{array}{l}\text { Diethylstilbesterol } \\
\text { (DES) }\end{array}$ \\
\hline Prazocin & & Estrone \\
\hline Indolocarbazole & & Antiestrogens \\
\hline topoisomerase I & & Tamoxifen, and deri- \\
\hline $\begin{array}{l}\text { inhibitors: NB-506, } \\
\text { J-107088 }\end{array}$ & & $\begin{array}{ll}\text { vatives } & \text { TAG-11, } \\
\text { TAG-139 } & \end{array}$ \\
\hline & & Toremifene \\
\hline $\begin{array}{l}\text { Zidovudine } \\
\text { lamivudine }\end{array}$ & & \\
\hline
\end{tabular}

${ }^{a}$ Effect varies, depending on the amino acid at codon 482 (see text)

ATP-dependent efflux of active phosphorylated metabolites of zidovudine (AZT) in a BCRP-overexpressing human $\mathrm{CD}^{+}{ }^{+} \mathrm{T}$-cell line (MT-4) was recently described. The activity of AZT and lamivudine against HIV-1 viral replication in these BCRP-overexpressing T cells was considerably reduced compared to parental MT-4 cells (Wang et al., 2003).

BCRP substrates and inhibitors are summarized in Table 2.

\section{Gene therapy approaches to modulating BCRP}

Modulation of the BCRP multidrug-resistant phenotype by a hammerhead ribozyme directed against the transporter has recently been reported (Kowalski et al., $2002,2001)$. When the anti-BCRP hammerhead ribozyme was introduced into the human gastric carcinoma cell line EPG85-257RNOV, the levels of BCRP mRNA and protein were greatly reduced and cellular accumulation of BCRP substrate drugs was increased.

BCRP transport function can be inhibited by dominant-negative BCRP mutants, strongly suggesting that homodimer formation is essential for BCRP function (Kage et al., 2002). BCRP mutants, generated by PCR mutagenesis, were transfected into PA317 cells and tested for the loss of BCRP function. A mutant with an amino-acid change from Leu to Pro at residue 554 in the fifth transmembrane domain of BCRP resulted in the loss of transporter function, and was able to reverse partially the drug resistance of cotransfected wild-type BCRP. The results suggest dominant-negative inhibition as a possible new strategy to circumvent clinical drug resistance. 


\section{Antibodies directed at BCRP}

Litman et al. (2000, 2002) developed polyclonal antibodies against several epitopes on BCRP. Rabbit anti-BCRP antisera 84705 was raised against an 18-mer peptide of the ATP-binding region of the protein and could detect BCRP polypeptide at a dilution of $1: 2000$. The antisera detected a well-defined $72 \mathrm{kDa}$ band corresponding to the predicted $\mathrm{MW}$ of the protein. Abundant expression of BCRP could be detected in MCF-7 AdVp3000 and S1-M1-80 cells by immunoblot assays and immunohistochemistry. Further Western analysis by Yang et al. (2000) demonstrated relative overexpression of BCRP in a topotecan-resistant subline MCF-7/TPT300.

Scheffer et al. (2000) developed a monoclonal antibody, BXP-34, by immunizing mice with MCF-7 Igrov1 MR cells and using a cytospin-based screening method with mitoxantrone-resistant and -sensitive cell lines. The BXP-34 monoclonal antibody, thus derived, was found to detect BCRP in the plasma membranes of the mitoxantrone-resistant cell lines MCF-7 Igrov1 MR, 8226 MR20, Igrov1 MX3, and the topotecan-resistant line Igrov1 T8. BXP-34 was able to detect a $72 \mathrm{kD}$ BCRP band in overexpressing cells by immunoprecipitation but not by Western blotting. A second monoclonal antibody, BXP21, was subsequently developed which, unlike BXP-34, can detect BCRP by immunoblotting and in formalinfixed paraffin-embedded tissues (Maliepaard et al., 2001a). These antibodies are now available commercially. BXP-34 and BXP-21 also allow detection of BCRP expression by flow cytometry in multiple BCRP-expressing cell lines (Minderman et al., 2002b). Flow cytometric analysis of FTC modulation of mitoxantrone retention has also been found to be a sensitive functional assay for BCRP transport suitable for analysis of clinical drug resistance (Minderman et al., 2002b). A new anti-human BCRP monoclonal antibody (clone 5D3; MAB4155, Chemicon), which recognizes an external epitope of BCRP on living cells, has also been developed for flow cytometry (Zhou et al., 2001).

\section{Cellular localization studies}

Immunohistochemical studies with monoclonal and polyclonal antibody probes confirm the predominant plasma membrane localization of the BCRP transporter. Initial studies with the 87405 antisera suggested cytoplasmic staining as well, but subsequent immunofluorescence studies with confocal microscopy and careful preadsorption of nonspecific binding antibodies demonstrated the predominance of plasma membrane immunostaining (Rocchi et al., 2000; Scheffer et al., 2000).

The plasma membrane location of BCRP differentiates this transporter from almost all other known halftransporters. Most half-transporters are predominantly localized to intracellular membranes, such as the mitochondria (M-ABC1 and $\mathrm{ABC}-7)$, the endoplasmic reticulum (TAP 1 and 2), or the peroxisomes (ALDP/
ABCD1). The only other half-transporter with evidence suggesting partial cell surface localization is the human white homologue ABCG1 (Ewart and Howells, 1998). Models for the Drosophila white protein also predict it to be localized in the plasma membrane of eye pigment cells (Ewart et al., 1994).

The results from immunohistochemical studies with BCRP antibodies have been corroborated by confocal microscopy drug localization assays performed in MCF7 and S1 parental cells and resistant sublines (Litman et al., 2000). Reduced cytoplasmic accumulation of mitoxantrone, daunorubicin, and topotecan was observed in the BCRP-expressing MCF-7 Adr-Vp3000 and S1-M1-80 sublines. In the S1-M1-80 cells, hot-spots consistent with accumulation in acidic vesicles were observed. Colocalization studies with lysotracker demonstrated sequestration of mitoxantrone in acidic vesicles in both parental S1 and resistant sublines (Litman et al., 2000).

\section{Kinetics of drug transport by BCRP}

Ozvegy et al. (2001) characterized the ATPase activity of $\mathrm{BCRP}$ in a variety of BCRP-overexpressing cell types, including Baculovirus-transfected Sf9 insect cells. BCRP demonstrates a baseline level of ATPase activity, which is 2-3-fold higher than that of Pgp. The ATPase activity in plasma membranes from these cells was vanadate sensitive, with a $K_{\mathrm{i}}$ of $8 \mu \mathrm{M}$, and was directly proportional to the amount of BCRP detected. The ATPase activity of BCRP demonstrated classical MichaelisMenten kinetics. The transporter showed specific ATP binding, but adenine nucleotide trapping could not be detected using 8-azido-ATP. The ATPase activity was stimulated by transport substrates of BCRP, such as mitoxantrone, prazosin, doxorubicin, daunorubicin, and rhodamine 123, but was inhibited by FTC. This ATPase assay could potentially be used as a screen to detect BCRP-drug interactions.

\section{Physiologic function of BCRP}

\section{Expression of BCRP in normal tissues}

We used BCRP cDNA as a probe in Northern blots to examine the expression of BCRP mRNA in selected normal human tissues (Doyle et al., 1998). The greatest expression was seen in placental tissue, which had approximately 100 times greater expression than brain, prostate, small intestine, testis, ovary, colon, or liver. BCRP transcripts were undetectable by Northern analysis in heart, lung, skeletal muscle, kidney, pancreas, spleen, thymus, and peripheral blood leukocytes. In subsequent studies, we used a commercially available dot blot that contained RNA from 50 human tissues (Human RNA Master Blot, Clontech). This blot was probed with a 795-bp cDNA probe corresponding to the $3^{\prime}$ portion of BCRP cDNA; quantification of probe 


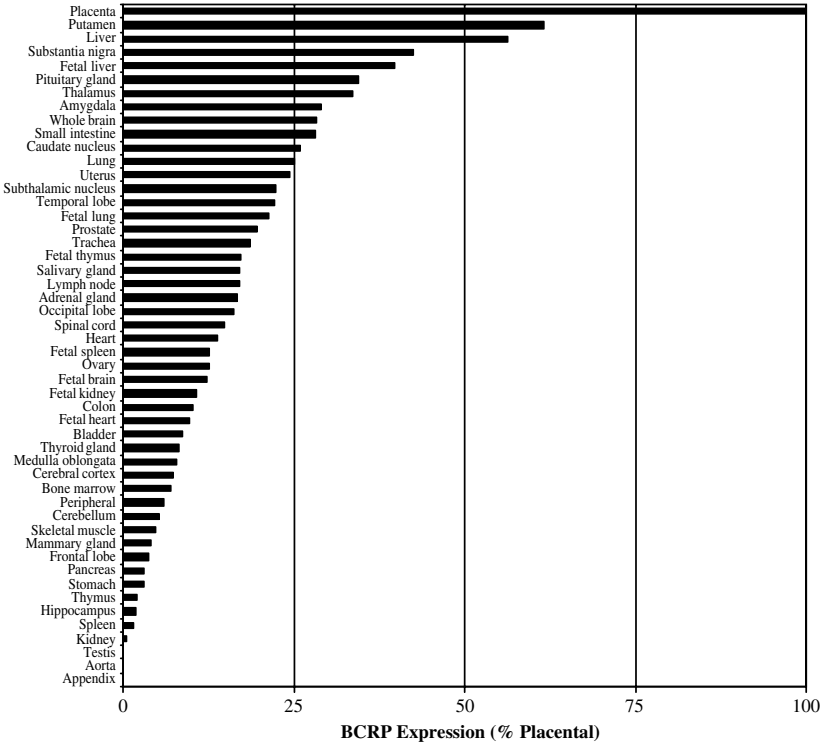

Figure 4 Multiple tissue dot blots using radiolabeled BCRP cDNA as probe. Blots were performed using Human RNA Master Blot (Clontech)

binding was carried out by Phosphorimager determination of the intensity of autoradiograpic image of each dot in the blot. As illustrated in Figure 4, placenta was again found to have the highest expression of BCRP mRNA. High expression was also seen in the liver and small intestine. Interestingly, certain areas of the brain (particularly the midbrain: putamen, substantia nigra, pituitary gland, thalamus, amygdala, caudate, and subthalamic nuclei) had relatively high expression of BCRP mRNA. In contrast to our earlier Northern blot studies, the dot blots showed moderate expression of BCRP in lung tissue, and low expression in testis, ovary, and colon.

Immunohistochemical studies with BXP-21 demonstrated moderate to strong BCRP expression in placenta, liver canaliculi, colon, small intestine, cardiac muscle, endocrine pancreas, adrenal cortex, thyroid, and parathyroid (Izquierdo et al., 2002). A weaker expression of BCRP was observed in other tissues such as hypophysis, prostate, bronchial epithelium, and peribronchial glands. In the kidneys, glomeruli were negative but faint BCRP expression was detected in certain tubules. While mouse kidney expresses high levels of BCRP expression by immunohistochemistry, human kidney does not (Schuetz et al., 2002). Normal tissues without detectable BCRP expression included endometrial cells and squamous epithelial cells in the skin or esophagus. BCRP is variably expressed by immunohistochemistry in normal breast epithelium and blood vessels (Faneyte et al., 2002). Low or undetectable BCRP expression in human and murine lung were also observed by immunohistochemical studies (Scheffer et al., 2002). The expression of BCRP in normal tissues as detected by immunohistochemistry is summarized in Table 3 .

Immunohistochemical studies of the placenta, using the monoclonal antibody BXP-34, suggest that BCRP
Table 3 Expression of BCRP in normal tissues, detected by immunohistochemistry

\begin{tabular}{lll}
\hline High & \multicolumn{1}{c}{ Intermediate } & \multicolumn{1}{c}{ Low } \\
\hline $\begin{array}{l}\text { Placental } \\
\text { syncytiotrophoblast }\end{array}$ & Hypophysis & Heart \\
Brain microvessel & Prostate & Lung \\
Endothelium (porcine & & Squamous epithelium - \\
human) & & skin and esophagus \\
Venules & Skeletal muscle \\
Kidney (mouse) & Kidney (human) \\
Small intestine & & Pancreas \\
Liver & Spleen \\
Testis & Thymus \\
Ovary & Peripheral blood \\
Colon & & leukocytes \\
\hline
\end{tabular}

expression is highest in the placental syncytiotrophoblast, at the apical surface of the chorionic villus (Maliepaard et al., 2001a). This localization suggests that BCRP plays a protective role for the fetus by effluxing drugs that enter the placenta back into the maternal circulation. Evidence for this hypothesis was provided by Jonker et al. (2000), who demonstrated that in pregnant, Pgp-deficient mice, fetal penetration of topotecan is increased at least twofold by the BCRP inhibitor GF120918. A recent review of efflux transporters in the human placenta is available (Young et al., 2003).

BCRP may also be an important component of the blood-brain barrier, excluding xenobiotics from the brain. The porcine homologue of BCRP was found in cultured brain capillary endothelial cells, which have high transendothelial electrical resistances and low cell monolayer permeabilities for small solutes very similar to the blood-brain barrier (Eisenblatter and Galla, 2002). Further analysis revealed that the porcine BCRP was expressed in brain tissue in vivo and was predominantly localized within the endothelial cells isolated from brain capillaries. The presence of BCRP in the luminal surface of the endothelium of human brain microvessels was recently demonstrated by immunofluorescence confocal microscopy (Cooray et al., 2002). This suggests that BCRP, like Pgp and MRP1, contributes to the blood-brain barrier.

The expression of porcine BCRP was induced in brain capillary endothelial cells by hydrocortisone (Eisenblatter and Galla, 2002), suggesting that this steroid may be a substrate for the transporter. Estrone and $17 \beta$-estradiol have been found to potentiate the cytotoxicity of SN-38, mitoxantrone, and topotecan in BCRP-transfected cells but not in a parental K562 line (Imai et al., 2002b). Estrone and $17 \beta$-estradiol also increased the cellular accumulation of topotecan in K562/BCRP cells. Since BCRP is expressed in the placenta, where these steroid hormones are produced, these findings suggest that BCRP may be important in the transport or secretion of these hormones or their precursors in the placenta.

\section{BCRP effects on drug bioavailability, pharmacokinetics}

Strong staining for BCRP was observed at the apical membrane of the small intestine and colon epithelium 
and in the bile canalicular membrane (Jonker et al., 2000). In fact, BCRP and MRP2 transcripts measured by quantitative PCR were more abundant in jejunum biopsies from healthy volunteers than were MDR1 transcripts (Taipalensuu et al., 2001). The apical localization of BCRP in gut tissue suggests a role of BCRP in reducing the uptake of orally administered BCRP substrates. In mice, Bcrp1 mediates apically directed transport of topotecan in the polarized kidney epithelial cell line LLC-PK1 (Jonker et al., 2000). The oral availability of topotecan is dramatically increased by oral coadministration of the Bcrp1 inhibitor GF120918 in both Pgp-deficient and wild-type mice. The plasma clearance and hepatobiliary excretion of topotecan were also decreased by GF120918. These findings suggest that BCRP plays an important role in the intestine and liver, limiting the oral availability of BCRP substrates by active backtransport of these molecules entering from the gut lumen. The role of transporters including BCRP in hepatobiliary transport is discussed in a recent review (Elferink and Groen, 2002).

Coadministration of GF120918 also resulted in a significant increase in the systemic exposure of oral topotecan in patients (Kruijtzer et al., 2002). The oral bioavailability of topotecan increased from $40 \%$ without to $97 \%$ with GF120918. Since topotecan has a much greater affinity for BCRP than Pgp, inhibition of BCRP by GF120918 is likely to be the major means by which the drug causes increased bioavailability of topotecan by increased intestinal absorption and reduced biliary excretion. Kruijtzer et al. (2002) also demonstrated evidence for decreased biliary and renal excretion of topotecan by GF120918 by showing that the drug reduces plasma clearance of topotecan administered intravenously. Newer camptothecin derivatives such as BNP1350, likely owe their superior oral bioavailability to the fact that they are poor substrates for BCRP (Van Hattum et al., 2002).

An important model for examining BCRP function has been developed by Allen et al. (1999), using mouse fibroblast cells lacking functional Mdrla, Mdr1b, and Mrpl genes. These cell lines were selected for resistance to topotecan, mitoxantrone, or doxorubicin. Each of the resultant drug-resistant cell lines demonstrated gene amplification of Bcrp1, the mouse homologue of the human gene, and elevated expression of Bcrp1 mRNA. Resistance to the three drugs in each cell line was completely reversed by coadministration of GF120918. These studies demonstrate that GF120918 reverses MDR in BCRP-overexpressing cells in which overexpression of Pgp species on Mrpl cannot contribute to the resistant phenotype.

\section{Expression and function of BCRP in stem cells}

Evidence is recently evolving that $\mathrm{ABC}$ transporters play a crucial role in the regulation of stem cell biology (Bunting, 2002). Hematopoietic stem cells from a variety of sources can be recognized with flow cytometry by their appearance as a 'side population' (SP) of cells, manifested by the ability of the stem cells to exclude the dye Hoechst
33342, and by cell surface phenotypic characteristics, including low or no expression of the CD34 antigen, and no expression of lineage markers (Goodell et al., 1997). Furthermore, SP cells are highly enriched in long-term culture-initiating cells (Goodell et al., 1997). Initial attention was drawn to Ppg as the transporter responsible for Hoechst dye exclusion in the SP cells; however, studies in Mdr1 knockout mice found no difference in the numbers of SP cells in the Pgp-deficient and Pgp-replete animals (Zhou et al., 2000, 2001; Uchida et al., 2002). SP cells from mouse or rhesus monkey sources were found to express high levels of BCRP mRNA (Zhou et al., 2001). Further, these investigators demonstrated that in primitive mouse hematopoietic stem cells $\left(\mathrm{CD} 34^{-}\right)$, BCRP mRNA was highly expressed; when the hematopoietic stem cells differentiated to a CD34 ${ }^{+}$phenotype, the expression of BCRP mRNA decreased markedly, with a concomitant increase in the expression of MRP1, -2 , and -4. The enforced expression of BCRP in bone marrow cells expanded the SP population, and caused a reduction in mature cell numbers, suggesting that BCRP is both a stem cell marker and an important determinant of the SP phenotype. These investigators postulated that possibly BCRP was preventing the cellular accumulation of a substrate requisite for the differentiation of the stem cells.

The demonstration that BCRP is an efficient Hoechst dye efflux pump, with overexpression in hematopoietic stem cells has been observed by other investigators (Kim et al., 2002; Scharenberg et al., 2002). Transfection of BCRP into human embryonic kidney cells generated an SP cell phenotype (Scharenberg et al., 2002). No Bcrp1 expression was seen in mature lymphoid or myeloid cells except for NK lymphocytes and Ter119+ erythroid precursor cells. Bcrpl was sharply downregulated upon differentiation of murine hematopoietic stem cells into lineage-specific development (Scharenberg et al., 2002).

Expression of Bcrpl was noted in $\mathrm{CD} 4^{+} / \mathrm{CD} 45^{-}$ murine myogenic-endothelial progenitor cells, which are resident in the interstitial spaces of mammalian skeletal muscle (Tamaki et al., 2002). BCRP expression has also been demonstrated in multipotential progenitor cells in islets isolated from adult human pancreas cells (Lechner et al., 2002). These cells, which exclude Hoechst dyes, might be useful for the production of islet tissue, which could be transplanted into diabetic subjects. The isolation of such stem cells might be facilitated by the use of a new anti-human BCRP monoclonal antibody (clone 5D3), which recognizes an external epitope of BCRP on living cells, and which has successfully been used to confirm marrow SP cells by flow cytometry (Zhou et al., 2001). Reviews concerning BCRP and the role of $\mathrm{ABC}$ transporters in stem cells are available (Bunting, 2002; Guo et al., 2003).

\section{Studies of BCRP-null mice}

Recently, Bcrp1-null mice have been developed (Zhou et al., 2002). These Bcrp1 $1^{-1-}$ mice display a marked reduction in SP cell numbers in both bone marrow and skeletal muscle. Interestingly, these mice had normal hematopoietic. However, hematopoietic stem cells 
from the Bcrp1-null mice were more sensitive to mitoxantrone, indicating a function of BCRP in protecting these cells from xenobiotic agents.

BCRP knockout mice were also produced independently by a group in the Netherlands (Jonker et al., 2002). These investigators found that the $\mathrm{Bcrp}^{-/-}$mice displayed photosensitivity in light-exposed areas of their skin. This phenomenon was attributed in part to absorption in the Bcrp1-null animals of a diet-derived compound pheophorbide a. Pheophorbide a is a breakdown product of chlorophyll. In Bcrp1-replete animals, absorption of pheophorbide was minimized by Bcrp1 transport back into the gut lumen. These investigators also found that the Bcrp1-null mice developed a novel protoporphyria, characterized by accumulation of protoporphyrin IX in erythrocytes. These studies suggest that humans with low or absent BCRP expression may be at risk for developing photosensitivity dependent on diet and protoporphyria.

\section{Expression of BCRP in human cancers}

\section{Leukemia studies (summarized in Table 4)}

Correlative studies in adult leukemia suggest the presence of a novel transport mechanism operative in some leukemic blast cells. MDR1/Pgp expression, which is highly correlated with cyclosporine-inhibited efflux by leukemic blasts, was noted in only $35 \%$ of younger acute myelogenous leukemia (AML) patients in a Southwest Oncology Group study, distinctly lower than the frequency of $71 \%$ previously reported in AML in the elderly (Leith et al., 1999). A distinct and nonoverlapping phenotype was detected in $18 \%$ of young AML cases: cyclosporine-resistant efflux not associated with MDR1, MRP1, or LRP expression, implying the existence of other as yet undefined efflux mechanisms in this malignancy.

Leukemia patients may benefit from treatment with cytotoxic drugs in combination with inhibitors of Pgp, but these patients may also be at particular risk to develop non-Pgp mechanisms of MDR. List et al. (1999) used cyclosporine in combination with daunorubicin in patients with AML. They found that Pgp-positive leukemic blasts were eliminated and that patients relapsed with a non-Pgp mechanism of drug resistance.

We have examined blast cells from 21 acute leukemia patients (one acute lymphoblastic leukemia (ALL), 20 AML) for BCRP expression with quantitative RT-PCR (Ross et al., 2000). Blast cells in seven patients with clinical drug-resistant disease had relatively high expression of BCRP mRNA. BCRP expression was low or barely detectable in blast cells from the remaining 14 patients. Expression of BCRP did not correlate with the expression of Pgp. However, other studies have demonstrated that high expression of BCRP correlated with an

Table 4 BCRP Expression in human leukemias

\begin{tabular}{|c|c|c|c|c|}
\hline Disease type & Number studied & Methods & Findings & Reference \\
\hline AML, ALL & $\begin{array}{l}20 \text { AML, one } \\
\text { ALL. In all, } 14 \\
\text { de novo, seven pre- } \\
\text { viously treated }\end{array}$ & RT-PCR & $\begin{array}{l}\text { BCRP mRNA expression varies } \\
\text { among samples. In all, } 33 \% \text { have } \\
\text { expression more than fivefold that } \\
\text { of the median value }\end{array}$ & Ross et al. (2000) \\
\hline AML & 20 paired samples & IHC, function & $\begin{array}{l}\text { BCRP correlated with immature } \\
\text { phenotype; no correlation in } \\
\text { relapsed/refractory disease }\end{array}$ & $\begin{array}{l}\text { van der Kolk et al. } \\
\text { (2002b) }\end{array}$ \\
\hline AML & 20 paired samples & $\begin{array}{l}\text { Real-time (Taqman) } \\
\text { RT-PCR }\end{array}$ & $\begin{array}{l}\text { BCRP expression increased in } \\
\text { relapsed/refractory disease }\end{array}$ & $\begin{array}{l}\text { van den Heuvel- } \\
\text { Eibrink et al. (2002) }\end{array}$ \\
\hline AML (newly diagnosed) & 40 & Real-time RT-PCR & $\begin{array}{l}\text { BCRP mRNA comparable to } \\
\text { expression in drug-resistant } \\
\text { BCRP-transfected cells in } 7 \% \text { of } \\
\text { patient samples }\end{array}$ & Abbott et al. (2002) \\
\hline AML & $\begin{array}{l}20 \text { ( } 12 \text { from } \\
\text { previously treated } \\
\text { patients) }\end{array}$ & $\begin{array}{l}\text { Immunohistochem- } \\
\text { istry (BXP-34 } \\
\text { monoclonal anti- } \\
\text { body) }\end{array}$ & $\begin{array}{l}\text { No correlation of BCRP expres- } \\
\text { sion with de novo versus previously } \\
\text { treated cases; patients with }+ \\
\text { BCRP expression had higher } \\
\text { LC }_{50} \text { to daunorubicin in vitro }\end{array}$ & Sargent et al. (2001) \\
\hline AML & 21 & $\begin{array}{l}\text { Real-time (Taqman) } \\
\text { RT-PCR }\end{array}$ & $\begin{array}{l}\text { BCRP expression correlated with } \\
\text { flavopiridol toxicity in vitro; } \\
\text { all samples expressed wild-type } \\
\text { (arginine) at codon } 482\end{array}$ & $\begin{array}{l}\text { Nakanishi et al. } \\
(2003)\end{array}$ \\
\hline ALL (childhood) & 67 & $\begin{array}{l}\text { Real-time (Taqman) } \\
\text { RT-PCR }\end{array}$ & $\begin{array}{l}\text { BCRP of no prognostic } \\
\text { significance }\end{array}$ & $\begin{array}{l}\text { Sauerbrey et al. } \\
(2002)\end{array}$ \\
\hline AML (childhood) & 59 & $\begin{array}{l}\text { Real-time (Taqman) } \\
\text { RT-PCR }\end{array}$ & $\begin{array}{l}\text { BCRP correlated with poor } \\
\text { response to remission induction } \\
\text { therapy }\end{array}$ & $\begin{array}{l}\text { Steinbach et al. } \\
(2002)\end{array}$ \\
\hline
\end{tabular}


immature phenotype, determined by expression of the surface marker CD34 $(R=0.54, P=0.001)$ (van der Kolk et al., 2002b). The association of BCRP expression with relapsed/refractory AML remains unclear. One study, using 20 paired clinical AML samples from diagnosis and relapse or refractory disease, demonstrated that BCRP was the only resistance protein that was expressed at a significantly higher RNA level (median 1.7-fold, $P=0.04$ ) in the relapsed/refractory state relative to that at diagnosis (van den HeuvelEibrink et al., 2002). However, a similar sized study, using flow cytometry with BXP-21 and BXP-34 monoclonal antibodies, as well as FTC-inhibitable mitoxantrone accumulation, did not demonstrate a consistent upregulation of BCRP in relapsed or refractory disease (van der Kolk et al., 2002b). A study of blast cell samples from 40 newly diagnosed AML patients revealed that $7 \%$ had BCRP expression comparable to BCRP-transfected cells with detectable functional activity; however, $78 \%$ of the samples expressed BCRP mRNA at levels higher than normal blood and bone marrow (Abbott et al., 2002).

BCRP expression has also been examined in relation to in vivo chemoresistance of leukemia blast cells from AML patients (Sargent et al., 2001). Six out of 22 AML samples had greater than $10 \%$ of cells staining positively for BCRP. Although there was no correlation between BCRP positivity and in vivo sensitivity to mitoxantrone, topotecan, or doxorubicin, the median daunorubicin $\mathrm{LC}_{50}$ value of $\mathrm{BCRP}(+)$ cells was fourfold higher than that of $\mathrm{BCRP}(-)$ cells $(P<0.05)$. The results are inconclusive but suggest that BCRP may be involved in resistance to one of the agents commonly used in front-line treatment of AML. These studies did not evaluate for mutations of the BCRP expressed at codon 482, the 'mutational hot-spot' found in drug-selected cells (Honjo et al., 2001a). In studies of blast cells from acute leukemia patients at the University of Maryland, we were able to correlate high expression of BCRP with in vitro resistance of the blast cells to flavopiridol (Nakanishi et al., 2003). In the region of BCRP mRNA corresponding to codon 482, all of the blast cell samples tested expressed the wild-type sequence.

A study of 47 initial stage and 20 relapsed children with ALL indicated low expression of BCRP, particularly in T-lineage ALL, and no prognostic significance of BCRP expression was observed (Sauerbrey et al., 2002). In contrast, this same group found that in childhood AML, BCRP expression was associated with a poor response to remission induction therapy (Steinbach et al., 2002).

The prognostic significance of BCRP and other transporters in leukemias is the subject of some recent review papers (Ross, 2000; van den Heuvel-Eibrink et al., 2000; van der Kolk et al., 2002a).

\section{Solid tumor studies (summarized in Table 5 )}

Initial immunohistochemical studies with monoclonal antibody BXP-34 using a panel of human tumors showed BCRP to be low or undetectable except for one case of small intestine adenocarcinoma (Scheffer et al., 2000). However, subsequent investigation by the same investigators, using a second monoclonal antibody, BXP-21, in formalin-fixed paraffin-embedded specimens, demonstrated BCRP immunoreactivity in over $40 \%$ of solid tumors tested (Diestra et al., 2002). These studies included 150 tumors from 21 different types of untreated cancer, and demonstrated weak to extremely strong BCRP immunoreactivity in some examples of most tumor types tested. BCRP reactivity was absent or low in bladder cancer, ovarian cancer, and small-cell carcinomas, but was detected in colon cancers, esophageal cancers, endometrial cancers, lung cancers, and melanoma, with staining of both cytoplasm and plasma membrane noted (Diestra et al., 2002). These results, if confirmed, have important implications as to the role of BCRP in clinical oncology.

Table 5 BCRP Expression in Human Solid Tumors

\begin{tabular}{|c|c|c|c|}
\hline Disease type & Number studied & Methods & Findings \\
\hline $\begin{array}{l}\text { Variety of solid tumors; } \\
16 \text { AML samples also }\end{array}$ & $\begin{array}{l}41 \text { solid tumor samples, all } \\
\text { but one pretreatment }\end{array}$ & $\begin{array}{l}\mathrm{IHC}^{\mathrm{a}} \mathrm{BXP}-34 \text { mono- } \\
\text { clonal antibody }\end{array}$ & $\begin{array}{l}\text { Low or undetectable BCRP } \\
\text { expression }\end{array}$ \\
\hline Breast Cancer & $\begin{array}{l}25 \text { primary, } 27 \text { pretreated } \\
\text { with anthracyclines }\end{array}$ & IHC & $\begin{array}{l}\text { BCRP not detected in tumor } \\
\text { tissue }\end{array}$ \\
\hline 21 types of solid tumors & $\begin{array}{l}150 \text { pretreatment samples, } \\
\text { formalin-fixed, paraffin- } \\
\text { embedded }\end{array}$ & $\begin{array}{l}\text { IHC a and Western blots, } \\
\text { BXP- } 34 \text {, BXP- } 21 \text { mono- } \\
\text { clonal antibodies }\end{array}$ & $\begin{array}{l}\text { Frequent expression of BCRP } \\
\text { staining with the BXP-21 anti- } \\
\text { body, confirmed by Western } \\
\text { blot. Highest expression was in } \\
\text { gastrointestinal adenocarcino- } \\
\text { mas, endometrial, and lung } \\
\text { carcinomas and myeloma. } \\
\text { Membrane and cytoplasmic } \\
\text { staining was observed. No } \\
\text { staining was observed with the } \\
\text { BXP-34 antibody under the } \\
\text { same conditions }\end{array}$ \\
\hline
\end{tabular}


The expression of BCRP in lung tumors was confirmed by Kawabata et al. (2001a), who used RT-PCR to detect low levels of BCRP in four of 12 lung cancer cell lines and approximately one-half of 44 lung tumor tissues tested. Topotecan efflux in the lung cancer cell lines correlated with the levels of BCRP mRNA expressed. The expression of BCRP in venules, as detected by immunohistochemistry, suggests that low levels of BCRP detected in tissue biopsies by PCR-based techniques must be interpreted with caution.

Ironically, despite its original isolation from multidrug-resistant human breast cancer cells, the level of BCRP expression in clinical breast cancer cases appears low by RT-PCR (Kanzaki et al., 2001). Immunohistochemical studies confirmed undetectable expression of BCRP in breast tumors, even in biopsies from women relapsing after doxorubicin-based chemotherapy (Faneyte et al., 2002).

Reviews of the role of BCRP in drug resistance of clinical cancers are available (Bates et al., 2001; Litman et al., 2001; Ejendal and Hrycyna, 2002).

\section{Unanswered questions and pending studies}

Current investigations of the BCRP transporter are in progress using models developed to characterize Pgp and MRP family members. The potential role for homodimerization and heterodimerization of the BCRP half-transporter adds a level of complexity of the studies required and limits the firmness of conclusions drawn about BCRP function. Conclusions regarding the substrate specificity of BCRP transport may also be limited by a lack of understanding of other necessary cofactors for transport. The physiologic function of BCRP is incompletely understood, although the localization of the protein to the placenta, lining cells of the intestine, and small blood vessels is suggestive for some normal functions of the protein. The expression of BCRP in the pluripotent SP stem cells from many tissues may allow the transporter to be used as a marker to define and characterize these interesting cells. Transplant studies with Bcrp1-transduced bone marrow cells are ongoing and suggest that expression of Bcrpl may have important functional effects in the stem cell compartment. The spectrum of drugs transported by BCRP and/or inhibiting BCRP function is evolving rapidly. The inhibition of BCRP by the tyrosine kinase inhibitors CI1033 and Iressa, for example, suggests the possibility that other clinically important quinazoline drugs may also be substrates and/or inhibitors of BCRP. Another way of revising BCRP-mediated resistance is to cleave the protein specifically using hammerhead ribozymes. A specific high-activity ribozyme directed at BCRP has recently been developed and found to cleave BCRP mRNA efficiently in a cell-free system (Kowalski et al., 2001, 2002).

The role of BCRP in clinical cancer resistance is currently under investigation, now that immunologic and other molecular probes have become available. Furthermore, the sequence at codon 482 should be investigated, particularly in studies relating the clinical response to anthracyclines or methotrexate with BCRP expression. BCRP may have a role in recurrent tumors, especially in hematologic malignancies in which patients have been treated with chemotherapy concurrent with inhibitors of Pgp. Ribozyme-based gene therapy may become clinically applicable in preventing or reversing BCRP-mediated drug resistance (van der Kolk et al., 2002b). Furthermore, inhibition of the BCRP transporter present at various tissue barriers may suggest ways to alter the pharmacokinetics of certain drugs. The oral coadministration of BCRP inhibitors could improve the intestinal availability of BCRP-substrate drugs such as topotecan and irinotecan. The use of new antibody probes, specific pharmacologic inhibitors, and animal models of BCRP function should allow rapid development of understanding of the physiologic and pathologic role of this interesting transporter.

\section{Abbreviations}

BCRP, breast cancer resistance protein; Pgp, P-glycoprotein; MRP1, multidrug resistance protein 1; MDR, multidrug resistance; FTC, fumitremorgin C; SP, side population.

\section{Acknowledgements}

We gratefully acknowledge Ms April Daniel for assistance in assembling the manuscript. We thank Dr Kimberly Bailey-Dell for performing the multiple tissue dot blots as part of her fulfillment of the requirements for a doctorate in philosophy at the University of Maryland School of Medicine. The authors' work is supported in part by NIH Grant RO1-CA77545 (LAD and DDR), and by a Department of Veterans Affairs Merit Review Grant to DDR.

\section{References}

Abbott BL, Colapietro AM, Barnes Y, Marini F, Andreeff M and Sorrentino BP. (2002). Blood, 100, 4594-4601.

Abele R and Tampe R. (1999). Biochim. Biophys. Acta, 1461, 405-419.

Allen JD, Brinkhuis RF, Wijnholds $\mathrm{J}$ and Schinkel AH. (1999). Cancer Res., 59, 4237-4241.

Allen JD, Jackson SC and Schinkel AH. (2002a). Cancer Res., 62, 2294-2299.

Allen JD, van Loevezijn A, Lakhai JM, van der Valk M, van Tellingen $\mathrm{O}$, Reid $\mathrm{G}$, Schellens $\mathrm{JH}$, Koomen GJ 
Bailey-Dell KJ, Hassel B, Doyle LA and Ross DD. (2001). Biochim. Biophys. Acta, 1520, 234-241.

Bates SE, Robey R, Miyake K, Rao K, Ross DD and Litman T. (2001). J. Bioenerg. Biomembr., 33, 503-511.

Borst P, Evers R, Kool M and Wijnholds J. (1999). Biochim. Biophys. Acta, 1461, 347-357.

Brangi M, Litman T, Ciotti M, Nishiyama K, Kohlhagen G, Takimoto C, Robey R, Pommier Y, Fojo T and Bates SE. (1999). Cancer Res., 59, 5938-5946.

Bunting KD. (2002). Stem Cells, 20, 11-20.

Chen WS, Luker KE, Dahlheimer JL, Pica CM, Luker GD and Piwnica-Worms D. (2000). Biochem. Pharmacol., 60, 413-426.

Chen YN, Mickley LA, Schwartz AM, Acton EM, Hwang JL and Fojo AT. (1990). J. Biol. Chem., 265, 10073-10080.

Chen YN, Rossierickley c, Lalioti MD, Lynn A, Chakravarti A, Perrin G and Antonarakis SE. (1996). Am. J. Hum. Genet., 59, 66-75.

Cole SP, Bhardwaj G, Gerlach JH, Mackie JE, Grant CE, Almquist KC, Stewart AJ, Kurz EU, Duncan AM and Deeley RG. (1992). Science, 258, 1650-1654.

Cole RJ and Cox RH. (1981). In Handbook of Toxic Fungal Metabolites. New York, Academic Press. Tremorgen Group, 355-509.

Cooray HC, Blackmore CG, Maskell L and Barrand MA. (2002). Neuroreport, 13, 2059-2063.

Croop JM, Tiller GE, Fletcher JA, Lux ML, Raab E, Goldenson D, Son D, Arciniegas S and Wu RL. (1997). Gene, 185, 77-85.

de Bruin M, Miyake K, Litman T, Robey R and Bates SE. (1999). Cancer Lett., 146, 117-126.

Diestra JE, Scheffer GL, Catala II, Maliepaard M, Schellens JH, Scheper RJ, Germa-Lluch JR and Izquierdo MA. (2002). J. Pathol., 198, 213-219.

Dietel M, Arps H, Lage H and Niendorf A. (1990). Cancer Res., 50, 6100-6106.

Doyle LA, Ross DD, Südhara R, Fojo AT, Kaufmann SH, Lee EJ and Scheffer CA. (1995). Br. J. Cancer, 71, 52-58.

Doyle LA, Yang W, Abruzzo LV, Krogmann T, Gao Y, Rishi AK and Ross DD. (1998). Proc. Natl. Acad. Sci. USA, 95, $15665-15670$.

Doyle LA, Yang W, Gao Y, Ordonez JV and Ross DD. (1996). Proc. Am. Soc. Clin. Oncol., 15, 398.

Eisenblatter T and Galla HJ. (2002). Biochem. Biophys. Res. Commun., 293, 1273-1278.

Ejendal and Hrycyna CA. (2002). Curr. Protein Pept. Sci., 3, 503-511.

Elferink RO and Groen AK. (2002). Biochim. Biophys. Acta, 1586, 129-145.

Erlichman C, Boerner SA, Hallgren CG, Spieker R, Wang XY, James CD, Scheffer GL, Maliepaard M, Ross DD, Bible KC and Kaufmann SH. (2001). Cancer Res., 61, 739-748.

Ewart GD, Cannell D, Cox GB and Howells AJ. (1994). J. Biol. Chem., 269, 10370-10377.

Ewart GD and Howells AJ. (1998). Methods Enzymol., 292, 213-224.

Faneyte IF, Kristel PM, Maliepaard M, Scheffer GL, Scheper RJ, Schellens JH and van de Vijver MJ. (2002). Clin. Cancer Res., 8, 1068-1074.

Futscher BW, Abbaszadegan MR, Domann F and Dalton WS. (1994). Biochem. Pharmacol., 47, 1601-1606.

Goodell MA, Rosenzweig M, Kim H, Marks DF, DeMaria M, Paradis G, Grupp SA, Sieff CA, Mulligan RC and Johnson RP. (1997). Nat. Med., 3, 1337-1345.
Guo Y, Lubbert M and Engelhardt M. (2003). Stem Cells, 21, 15-20.

Hausner P, Venzon DJ, Grogan L and Kirsch IR. (1999). Neoplasia, 1, 356-367.

Hazlehurst LA, Foley NE, Gleason-Guzman MC, Hacker MP, Cress AE, Greenberger LW, De Jong MC and Dalton WS. (1999). Cancer Res., 59, 1021-1028.

Higgins CF. (1995). Cell, 82, 693-696.

Honjo Y, Hrycyna CA, Yan QW, Medina-Perez WY, Robey RW, van de Laar A, Litman T, Dean $M$ and Bates SE. (2001a). Cancer Res., 61, 6635-6639.

Honjo Y, Robey R, Yan QW, Litman T, van de Laar A, Covitz M, Hrycyna C and Bates S. (2001b). Third FEBS Advanced Lecture Course on ATP-Binding Cassette (ABC) Proteins: From Multidrug Resistance to Genetic Diseases Gosau, Austria (abstract).

Honjo Y, Robey RW, Dean M, Hrycyna C and Bates SE. (2002). Proc. Am. Assoc. Cancer Res., 43, 778 (abstract 3858).

Imai Y, Nakane M, Kage K, Tsukahara S, Ishikawa E, Tsuruo T, Miki Y and Sugimoto Y. (2002a). Mol. Cancer Ther., 1, 611-616.

Imai Y, Tsukahara S, Ishikawa E, Tsuruo T and Sugimoto Y. (2002b). Jpn. J. Cancer Res., 93, 231-235.

Ishii M, Iwahana M, Mitsui I, Minami M, Imagawa S, Tohgo A and Ejima A. (2000). Anticancer Drugs, 11, 353-362.

Izquierdo MA, Diestra JE, Condom E, Scheffer GL and Germa-Lluch JR. (2002). Proc. Am. Assoc. Cancer Res., 43, 77 (abstract 3854).

Jonker JW, Buitelaar M, Wagenaar E, Van Der Valk MA, Scheffer GL, Scheper RJ, Plosch T, Kuipers F, Oude Elferink RP, Rosing H, Beijnen JH and Schinkel AH. (2002). Proc. Natl. Acad. Sci. USA, 12, 15649-15654.

Jonker JW, Smit JW, Brinkhuis RF, Maliepaard M, Beijnen JH, Schellens JH and Schinkel AH. (2000). J. Natl. Cancer Inst., 92, 1651-1656.

Juliano RL and Ling V. (1976). Biochim. Biophys. Acta, 455, $152-162$

Kage K, Tsukahara S, Sugiyama T, Asada S, Ishikawa E, Tsuruo T and Sugimoto Y. (2002). Int. J. Cancer, 97, 626-630.

Kanzaki A, Toi M, Nakayama K, Bando H, Mutoh M, Uchida T, Fukumoto M and Takebayashi Y. (2001). Jpn. J. Cancer Res., 92, 452-458.

Kawabata S, Oka M, Nakatomi K, Shiozawa K, Kasai T, Fukuda M, Soda H and Kohno S. (2001a). Proc. Am. Assoc. Cancer Res., 42, 930 (abstract 4995).

Kawabata S, Oka M, Shiozawa K, Tsukamoto K, Nakatomi K, Soda H, Fukuda M, Ikegami Y, Sugahara K, Yamada Y, Kamihira S, Doyle LA, Ross DD and Kohno S. (2001b). Biochem. Biophys. Res. Commun., 280, 1216-1223.

Kim M, Turnquist H, Jackson J, Sgagias M, Yan Y, Gong M, Dean M, Sharp JG and Cowan K. (2002). Clin. Cancer Res., 8, 22-28.

Klucken J, Buchler C, Orso E, Kaminski WE, PorschOzcurumez M, Liebisch G, Kapinsky M, Diederich W, Drobnik W, Dean M, Allikmets R and Schmitz G. (2000). Proc. Natl. Acad. Sci. USA, 97, 817-822.

Knutsen T, Rao VK, Ried T, Mickley L, Schneider E, Miyake K, Ghadimi BM, Padilla-Nash H, Pack S, Greenberger L, Cowan K, Dean M, Fojo T and Bates S. (2000). Genes Chromosomes Cancer, 27, 110-116.

Komatani H, Kotani H, Hara Y, Nakagawa R, Matsumoto M, Arakawa H and Nishimura S. (2001). Cancer Res., 61, 2827-2832. 
Kowalski P, Stein U, Scheffer GL and Lage H. (2002). Cancer Gene Ther., 9, 579-586.

Kowalski P, Wichert A, Holm PS, Dietel M and Lage $\mathrm{H}$ (2001). Cancer Gene Ther., 8, 185-192.

Kruijtzer CM, Beijnen JH, Rosing $\mathrm{H}$, ten Bokkel Huinink WW, Schot M, Jewell RC, Paul EM and Schellens JH. (2002). J. Clin. Oncol., 20, 2943-2950.

Langmann T, Porsch-Ozcurumez M, Unkelbach U, Klucken J and Schmitz G. (2000). Biochim. Biophys. Acta, 1494, 175-180.

Laurand A, Laroche-Clary A, Larrue A, Bonnet $\mathbf{J}$ and Robert J. (2001). Proc. Am. Assoc. Cancer Res., 42, 647 (abstract 3483).

Lechner A, Leech CA, Abraham EJ, Nolan AL and Habener JF. (2002). Biochem. Biophys. Res. Commun., 293, 670-674

Lee JS, Scala S, Matsumoto Y, Dickstein B, Robey R, Zhan Z, Altenberg G and Bates SE. (1997). J. Cell. Biochem., 65, $513-526$

Leith CP, Kopecky KJ, Chen IM, Eijdems L, Slovak ML, McConnell TS, Head DR, Weick J, Grever MR, Appelbaum FR and Willman CL. (1999). Blood, 94, 1086-1099.

List AF, Kopecky KJ, Willman CL, Spier C, Dorr R, Appelbaum F and Hynes H. (1999). Blood, 92, 312a.

Litman T, Brangi M, Hudson E, Fetsch P, Abati A, Ross DD, Miyake K, Resau JH and Bates SE. (2000). J. Cell. Sci., 113, 2011-2021.

Litman T, Druley TE, Stein WD and Bates SE. (2001). Cell Mol. Life Sci., 58, 931-959.

Litman T, Jensen U, Hansen A, Covitz K, Zhan Z, Fetsch P, Abati A, Hansen P, Horn T, Skovsgaard T and Bates S. (2002). Biochim. Biophys. Acta, 1565, 6-16.

Maliepaard M, Scheffer GL, Faneyte IF, van Gastelen MA, Pijnenborg AC, Schinkel AH, van De Vijver MJ, Scheper RJ and Schellens JH. (2001a). Cancer Res., 61, 3458-3464.

Maliepaard M, van Gastalen MA, de Jong LA, Pluim D, van Waardenburg RCAM, Ruevekamp-Helmers MC and Schellens JHM. (2000). Proc. Am. Assoc. Cancer Res., 41, 268 (abstract 1705).

Maliepaard M, van Gastelen MA, de Jong LA, Pluim D, van Waardenburg RC, Ruevekamp-Helmers MC, Floot BG and Schellens JH. (1999). Cancer Res., 59, 4559-4563.

Maliepaard M, van Gastelen MA, Tohgo A, Hausheer FH, van Waardenburg RC, de Jong LA, Pluim D, Beijnen JH and Schellens JH. (2001b). Clin. Cancer Res., 7, 935-941.

Minderman H, Suvannasankha A, O'Loughlin KL, Allen J Schinkel A, Scheper RJ, Scheffer GL, Robey RW, Bates SE and Baer MR. (2002a). Proc. Am. Assoc. Cancer Res., 43, 493 (abstract 2465).

Minderman H, Suvannasankha A, O'Loughlin KL, Scheffer GL, Scheper RJ, Robey RW and Baer MR. (2002b). Cytometry, 48, 59-65.

Miyake K, Mickley L, Litman T, Zhan Z, Robey R, Cristensen B, Brangi M, Greenberger L, Dean M, Fojo T and Bates SE. (1999). Cancer Res., 59, 8-13.

Nakagawa M, Schneider E, Dixon KH, Horton J, Kelley K, Morrow C and Cowan KH. (1992). Cancer Res., 52, 6175-6181.

Nakanishi T, Karp JE, Tan M, Doyle LA, Peters T, Yang W, Wei D and Ross DD. (2003). Clin. Cancer Res., 9, $3320-3328$

Nakatomi K, Yoshikawa M, Oka M, Ikegami Y, Hayasaka S, Sano K, Shiozawa K, Kawabata S, Soda H, Ishikawa T, Tanabe S and Kohno S. (2001). Biochem. Biophys. Res. Commun., 288, 827-832.
Ozvegy C, Litman T, Szakacs G, Nagy Z, Bates S, Varadi A and Sarkadi B. (2001). Biochem. Biophys. Res. Commun., 285, 111-117.

Ozvegy C, Varadi A and Sarkadi B. (2002). J. Biol. Chem., 8, 8.

Perego P, De Cesare M, De Isabella P, Carenini N, Beggiolin G, Pezzoni G, Palumbo M, Tartaglia L, Pratesi G, Pisano C, Carminati P, Scheffer GL and Zunino F. (2001). Cancer Res., 61, 6034-6037.

Rabindran SK, He H, Singh M, Brown E, Collins KI, Annable T and Greenberger LM. (1998). Cancer Res., 58, 5850-5858.

Rabindran SK, Ross DD, Doyle LA, Yang W and Greenberger LM. (2000). Cancer Res., 60, 47-50.

Rajendra R, Gounder MK, Ahamed S, Schellens JHM, Ross DD, Sinko P and Rubin EH. (2002). Proc. Am. Assoc. Cancer Res., 43, 777 (abstract 3853).

Robey RW, Honjo Y, van de Laar A, Miyake K, Regis JT, Litman T and Bates SE. (2001a). Biochim. Biophys. Acta, 1512, 171-182.

Robey RW, Medina-Perez WY, Nishiyama K, Lahusen T, Miyake K, Litman T, Senderowicz AM, Ross DD and Bates SE. (2001b). Clin. Cancer Res., 7, 145-152.

Rocchi E, Khodjakov A, Volk EL, Yang CH, Litman T, Bates SE and Schneider E. (2000). Biochem. Biophys. Res. Commun., 271, 42-46.

Ross DD. (2000). Leukemia, 14, 467-473.

Ross DD, Doyle LA, Yang W, Tong Y and Cornblatt B. (1995). Biochem. Pharmacol., 50, 1673-1683.

Ross DD, Karp JE, Chen TT and Doyle LA. (2000). Blood, 96, 365-368.

Ross DD, Yang W, Abruzzo LV, Dalton WS, Schneider E, Lage H, Dietel M, Greenberger L, Cole SP and Doyle LA. (1999). J. Natl. Cancer Inst., 91, 429-433.

Sargent JM, Williamson CJ, Maliepaard M, Elgie AW, Scheper RJ and Taylor CG. (2001). Br. J. Haematol., 115, 257-262.

Sauerbrey A, Sell W, Steinbach D, Voigt A and Zintl F. (2002). Br. J. Haematol., 118, 147-150.

Scharenberg CW, Harkey MA and Torok-Storb B. (2002). Blood, 99, 507-512.

Scheffer GL, Maliepaard M, Pijnenborg AC, van Gastelen MA, de Jong MC, Schroeijers AB, van der Kolk DM, Allen JD, Ross DD, van der Valk P, Dalton WS, Scheffer GL, Pijnenborg AC, Smit EF, Muller M, Postma DS, Timens W, van der Valk P, de Vries EG and Scheper RJ. (2000). Cancer Res., 55, 332-339.

Scheffer GL, Pijnenborg AC, Smit EF, Muller M, Postma DS, Timens W, van der Valk P, de Vries EG and Scheper RJ. (2002). J. Clin. Pathol., 60, 2589-2593.

Schellens JHM, Van Eijndhoven M, van Waardenburg RC, de Jong E, Schinkel AH and Beijnen JH. (2002). Proc. Am. Assoc. Cancer Res., 43, 1154 (abstract 5723).

Schlegel S, Klimecki W and List AF. (1999). Proc. Am. Assoc. Cancer Res., 40, 669 (abstract 4415).

Schuetz JD, Leggas M, Sampath J, Wall A, Lan L, Cheshire PJ, Peterson J, Stewart CF and Houghton PJ. (2002). Proc. Am. Assoc. Cancer Res., 43, 272 (abstract 1351).

Senderowicz AM. (1999). Invest. New Drugs, 17, 313-320.

Stein U, Lage H, Jordan A, Walther W, Bates SE, Litman T, Hohenberger P and Dietel M. (2002). Int. J. Cancer, 97, 751-760.

Steinbach D, Sell W, Voigt A, Hermann J, Zintl F and Sauerbrey A. (2002). Leukemia, 16, 1443-1447. 
Sugimoto $\mathrm{Y}$, Tsukahara $\mathrm{S}$, Imai $\mathrm{Y}$, Ueda $\mathrm{K}$ and Tsuruo $\mathrm{T}$. (2003). Mol. Cancer Ther., 2, 105-112.

Taipalensuu J, Tornblom H, Lindberg G, Einarsson C, Sjoqvist F, Melhus H, Garberg P, Sjostrom B, Lundgren B and Artursson P. (2001). J. Pharmacol. Exp. Ther., 299, 164 170.

Takebayashi Y, Nakayama K, Fujioka T, Kanzaki A, Mutho M, Uchida T, Miyazaki K, Ito M and Fukumoto M. (2001). Int. J. Mol. Med., 7, 397-400.

Tamaki T, Akatsuka A, Ando K, Nakamura Y, Matsuzawa H, Hotta T, Roy RR and Edgerton VR. (2002). J. Cell Biol., 157, 571-577.

Taylor CW, Dalton WS, Parrish PR, Gleason MC, Bellamy WT, Thompson FH, Roe DJ and Trent JM. (1991). Br. J. Cancer, 63, 923-929.

Thompson JD, Gibson TJ, Plewniak F, Jeanmougin F and Higgins DG. (1997). Nucleic Acids Res., 25, 4876-4882.

Uchida N, Leung FY and Eaves CJ. (2002). Exp. Hematol., 30, 862-869.

Ueda K, Pastan I and Gottesman MM. (1987). J. Biol. Chem., 262, 17432-17436.

van den Heuvel-Eibrink MM, Sonneveld $\mathrm{P}$ and Pieters R. (2000). Int. J. Clin. Pharmacol. Ther., 38, 94-110.

van den Heuvel-Eibrink MM, Wiemer EA, Prins A, Meijerink JP, Vossebeld PJ, van der Holt B, Pieters R and Sonneveld P. (2002). Leukemia, 16, 833-839.

van der Kolk DM, de Vries EG, Muller M and Vellenga E. (2002a). Leukemia Lymphoma, 43, 685-701.

van der Kolk DM, Vellenga E, Scheffer GL, Muller M, Bates SE, Scheper RJ and de Vries EG. (2002b). Blood, 99, 3763-3770.

Van Hattum AH, Schluper HM, Hausheer FH, Pinedo HM and Boven E. (2002). Int. J. Cancer, 100, 22-29.

Van Hattum AH, Schluper HMM, Pinedo HM and Boven E. (2001). Proc. Am. Assoc. Cancer Res., 42, 815 (abstract 4372). van Loevezijn A, Allen JD, Schinkel AH and Koomen GJ. (2001). Bioorg. Med. Chem. Lett., 11, 29-32.

Volk EL, Farley KM and Schneider E. (2002a). Proc. Am. Assoc. Cancer Res., 43, 780 (abstract 3866).

Volk EL, Farley KM, Wu Y, Li F, Robey RW and Schneider E. (2002b). Cancer Res., 62, 5035-5040.

Volk EL, Rohde K, Rhee M, McGuire JJ, Doyle LA, Ross DD and Schneider E. (2000). Cancer Res., 60, $3514-3521$.

Wang X, Furukawa T, Nitanda T, Okamoto M, Sugimoto Y, Akiyama S and Baba M. (2003). Mol. Pharmacol., 63, 65-72.

Yang CH, Schneider E, Kuo ML, Volk EL, Rocchi E and Chen YC. (2000). Biochem. Pharmacol., 60, 831-837.

Yoshikawa M, Hayasaka S, Ikegami Y, Satake K, Ito A, Sano K, Suzuki T, Togawa T, Ishii K, Yoshida $H$, Oka M, Yabuuchi H, Sawada S, Tanabe S and Ishikawa T. (2002). Proc. Am. Assoc. Cancer Res., 43, 777 (abstract 3852).

Young AM, Allen CE and Audus KL. (2003). Adv. Drug Deliv. Rev., 55, 125-132.

Zamber CP, Lamba JK, Yasuda K, Farnum J, Thummel K, Schuetz JD and Schuetz EG. (2003). Pharmacogenetics, 13, 19-28.

Zhou S, Morris JJ, Barnes Y, Lan L, Schuetz JD and Sorrentino BP. (2002). Proc. Natl. Acad. Sci. USA, 99, 12339-12344.

Zhou S, Morris JJ, Bunting KD, Osawa M, Schuetz JD, Nakauchi H and Sorrentino BP. (2000). Blood (Suppl.), 96, 820a (abstract 3545).

Zhou S, Schuetz JD, Bunting KD, Colapietro AM, Sampath J, Morris JJ, Lagutina I, Grosveld GC, Osawa M, Nakauchi H and Sorrentino BP. (2001). Nat. Med., 7, 1028-1034.

Zhu Q and Center MS. (1994). Cancer Res., 54, 4488-4492. 